\title{
Phosphate Coatings Enriched with Copper on Titanium Substrate Fabricated Via DC-PEO Process
}

\author{
Krzysztof Rokosz ${ }^{1, *}$, Tadeusz Hryniewicz ${ }^{1}$ (D) Wojciech Kacalak ${ }^{1}$, Katarzyna Tandecka ${ }^{1}(\mathbb{D}$, \\ Steinar Raaen ${ }^{2}$, Sofia Gaiaschi ${ }^{3}$, Patrick Chapon ${ }^{3}$, Winfried Malorny ${ }^{4}$, Dalibor Matýsek ${ }^{5}$, \\ Kornel Pietrzak ${ }^{1}$ and Lukasz Dudek ${ }^{1}$ (D)
}

1 Department of Engineering and Informatics Systems, Faculty of Mechanical Engineering, Koszalin University of Technology, 75620 Koszalin, Poland; Tadeusz.Hryniewicz@tu.koszalin.pl (T.H.); Wojciech.Kacalak@tu.koszalin.pl (W.K.); Katarzyna.Tandecka@tu.koszalin.pl (K.T.);

kornel.pietrzak@s.tu.koszalin.pl (K.P.); lukasz.dudek@tu.koszalin.pl (Ł.D.)

2 Department of Physics, Norwegian University of Science and Technology (NTNU), 7491 Trondheim, Norway; steinar.raaen@ntnu.no

3 HORIBA FRANCE S.A.S., Boulevard Thomas Gobert - Passage Jobin Yvon, 91120 Palaiseau, France; sofia.gaiaschi@horiba.com (S.G.); patrick.chapon@horiba.com (P.C.)

4 Hochschule Wismar-University of Applied Sciences Technology, Business and Design, Faculty of Engineering, 23966 Wismar, Germany; winfried.malorny@hs-wismar.de

5 Institute of Geological Engineering, Faculty of Mining and Geology, VŠB-Technical University of Ostrava, 70833 Ostrava, Czech Republic; dalibor.matysek@vsb.cz

* Correspondence: rokosz@tu.koszalin.pl; Tel.: +48-94-3478354

Received: 7 February 2020; Accepted: 10 March 2020; Published: 13 March 2020

\begin{abstract}
The present paper covers the possible ways to fabricate advanced porous coatings that are enriched in copper on a titanium substrate through Direct Current Plasma Electrolytic Oxidation (DC-PEO) with voltage control, in electrolytes made of concentrated orthophosphoric acid with the addition of copper(II) nitrate(V) trihydrate. In these studies, solutions containing from 0 to $650 \mathrm{~g}$ salt per $1 \mathrm{dm}^{3}$ of acid and anodic voltages from $450 \mathrm{~V}$ up to $650 \mathrm{~V}$ were used. The obtained coatings featuring variable porosity could be best defined by the three-dimensional (3D) parameter $S z$, which lies in the range 9.72 to $45.18 \mu \mathrm{m}$. The use of copper(II) nitrate(V) trihydrate in the electrolyte, resulted, for all cases, in the incorporation of the two oxidation forms, i.e., $\mathrm{Cu}^{+}$and $\mathrm{Cu}^{2+}$ into the coatings. Detailed X-Ray Photoelectron Spectroscopy (XPS) studies layers allowed for stating that the percentage of copper in the surface layer of the obtained coatings was in the range of 0.24 at $\%$ to 2.59 at $\%$. The X-Ray Diffraction (XRD) studies showed the presence of copper $\left(\alpha-\mathrm{Cu}_{2} \mathrm{P}_{2} \mathrm{O}_{7}\right.$, and $\left.\mathrm{Cu}_{3}\left(\mathrm{PO}_{4}\right)_{2}\right)$ and titanium $\left(\mathrm{TiO}_{2}\right.$-anatase, $\mathrm{TiO}_{3}, \mathrm{TiP}_{2} \mathrm{O}_{7}$, and $\left.\mathrm{Ti}_{0.73} \mathrm{O}_{0.91}\right)$ compounds in coatings. From Energy-Dispersive X-Ray Spectroscopy (EDS) and XPS studies, it was found that the Cu/P ratio increases with the increase of voltage and the amount of salt in the electrolyte. The depth profile analysis by Glow-Discharge Optical Emission Spectroscopy (GDOES) method showed that a three-layer model consisting of a top porous layer, a semi-porous layer, and a transient/barrier layer might describe the fabricated coatings.
\end{abstract}

Keywords: plasma electrolytic oxidation (PEO); micro arc oxidation (MAO); titanium; copper(II) nitrate $(\mathrm{V})$ trihydrate; orthophosphoric acid

\section{Introduction}

The Plasma Electrolytic Oxidation (PEO) process, which is known also under the name of Micro Arc Oxidation (MAO), is used to fabricate porous coatings on light metals substrates, such as titanium and its alloys. The PEO coatings can be used as transition layers between the bones and implants 
because of their chemical composition. They are also interesting background substrates for catalysts. Previous studies of the authors have proved that it is possible to obtain porous coatings on titanium [1] and its alloys [2,3], which are enriched with selected chemical elements, during the PEO processes under both Direct Current (DC) [1-3] or Alternating Current (AC) [4] voltage conditions in electrolytes that are based on orthophosphoric acid. It is important that most of the research teams all over the world involved in the fabrication and characterization of such coatings on pure titanium or on its alloys are using water electrolytes, as shown in Table 1. Most of presented electrolytes, which are based on sodium hexametaphosphate, sodium pyrophosphate, trisodium phosphate, as well as sodium and calcium dihydrogen phosphates with the addition of selected compounds, influenced the improvement of the mechanical and electrochemical properties. It has to be pointed out that additional antibacterial protection can be obtained by fabrication of PEO coatings in solutions mostly containing silver or copper ions, which may be obtained by the use of $\mathrm{CH}_{3} \mathrm{COOAg}$ [5] or $\mathrm{Cu}\left(\mathrm{CH}_{3} \mathrm{COO}\right)_{2}$ [6], respectively. It was also indicated that thermal treatment essentially affects the surface roughness and its wettability, without affecting the titanium, calcium, and phosphorus oxidation levels that are present in the coating [7]. The surface roughness and its wettability are connected with the biocompatibility of the material and proliferation properties of coatings applied in implants. However, it was pointed out that, for medical applications, the optimization of the oxide surface properties is of extreme importance and a necessity [8]. In addition, increasing the values of roughness parameters might result in a limitation of the adhesion of the cells to the coating, which leads to a reduced ability for proliferation. The effect of the diameter of the titanium sphere structures on the porosity of the PEO coatings and chemical compounds of titanium with oxygen that formed in the obtained coatings was also proved [9].

On the other hand, it is the studies of the mechanical properties of PEO coatings obtained on titanium alloy in aqueous electrolytes with the additions of $\mathrm{NaAlO}_{2}, \mathrm{Na}_{3} \mathrm{PO}_{4}, \mathrm{Na}_{2} \mathrm{SiO}_{3}$, and $\mathrm{KOH}$ have proved that using an electrolyte composition of $\mathrm{NaAlO}_{2}$ with $\mathrm{Na}_{3} \mathrm{PO}_{4}$ offers considerable improvement of the mechanical properties when compared to the ones of the alloy surface before its modification [10]. The presence of anatase and rutile on the alloy surfaces in an aqueous solution of $\mathrm{Na}_{3} \mathrm{PO}_{4}$ allowed for potential use in photocatalysis [11].

Table 1. Examples of water electrolytes containing phosphates and poly-phosphates compounds used in plasma electrolytic oxidation processes.

\begin{tabular}{|c|c|}
\hline Electrolytes & Ref. \\
\hline$\left(\mathrm{NaPO}_{3}\right)_{6}, \mathrm{NaF}, \mathrm{NaAlO}_{2}$ & [12] \\
\hline$\left(\mathrm{NaPO}_{3}\right)_{6}, \mathrm{CaO}, \mathrm{Na}_{2} \mathrm{H}_{2} \mathrm{EDTA}, \mathrm{KOH}$ & [13] \\
\hline$\left(\mathrm{NaPO}_{3}\right)_{6}, \mathrm{Na}_{2} \mathrm{SiO}_{3}, \mathrm{NaAlO}_{2}$ & [14] \\
\hline $\mathrm{Na}_{4} \mathrm{P}_{2} \mathrm{O}_{7}, \mathrm{KOH}, \mathrm{NaAlO}_{2}$ & [15] \\
\hline $\mathrm{Na}_{3} \mathrm{PO}_{4},\left(\mathrm{NH}_{4}\right)_{2} \mathrm{HPO}_{4}, \mathrm{C}_{2} \mathrm{H}_{7} \mathrm{NO}_{2}, \mathrm{KOH}, \mathrm{Na}_{2} \mathrm{SO}_{4},\left(\mathrm{HOCH}_{2}\right)_{3} \mathrm{CNH}_{2}$ & [16] \\
\hline $\mathrm{Na}_{3} \mathrm{PO}_{4}, \mathrm{Na}_{2} \mathrm{~B}_{4} \mathrm{O}_{7}, \mathrm{Na}_{3} \mathrm{WO}_{4}$ & [17] \\
\hline $\mathrm{Na}_{3} \mathrm{PO}_{4}, \alpha-\mathrm{Al}_{2} \mathrm{O}_{3}$ & [18] \\
\hline $\mathrm{Na}_{3} \mathrm{PO}_{4}, \mathrm{Na}_{2} \mathrm{SiO}_{3}$ & {$[14]$} \\
\hline $\mathrm{Na}_{3} \mathrm{PO}_{4}, \mathrm{FeSO}_{4}, \mathrm{Co}\left(\mathrm{CH}_{3} \mathrm{COO}\right)_{2}, \mathrm{Ni}\left(\mathrm{CH}_{3} \mathrm{COO}\right)_{2}, \mathrm{~K}_{2} \mathrm{ZrF}_{6}$ & [19] \\
\hline $\mathrm{Na}_{3} \mathrm{PO}_{4}, \mathrm{FeSO}_{4}$ & [20] \\
\hline $\mathrm{Na}_{3} \mathrm{PO}_{4}, \mathrm{Co}\left(\mathrm{CH}_{3} \mathrm{COO}\right)_{2}$ & [21] \\
\hline $\mathrm{Na}_{3} \mathrm{PO}_{4}, \mathrm{NaAlO}_{2}, \mathrm{KOH}, \mathrm{NaCl}$ & [22] \\
\hline $\mathrm{NaH}_{2} \mathrm{PO}_{4},\left(\mathrm{CH}_{3} \mathrm{COO}\right)_{2} \mathrm{Ca}$ & [23] \\
\hline $\mathrm{Ca}\left(\mathrm{H}_{2} \mathrm{PO}_{4}\right)_{2}, \mathrm{CaO}, \mathrm{Na}_{2}(\mathrm{EDTA}), \mathrm{Na}_{2} \mathrm{SiO}_{3}$ & [24] \\
\hline
\end{tabular}

EDTA - ethylenediaminetetraacetic acid.

In this current paper, we will therefore present some complex multivariate analysis of our coatings involving both the chemical and the phase compositions, together with roughness aspects that are related to the changes of electrolytes' composition and PEO voltages. We propose also mathematical formulae that will help in predicting this surface roughness as well as the chemical and phase 
compositions from the parameters of the process - an information that is not attainable so far in the available literature.

\section{Materials and Methods}

Commercially Pure Titanium Grade 2 samples $(1000 \mathrm{~mm} \times 10 \mathrm{~mm} \times 2 \mathrm{~mm})$ were used for all experiments. The preparation procedure and PEO set up on DC Power Supply (Kikusui PWR 1600H, Kikusui Electronics Corporation, Yokohama, Kanagawa, Japan) as well as the coatings' characterization methods, such as: SEM (FEI Quanta 250, Field Electron and Iron Company, Hillsboro, OR, USA), EDS (ultra-dry EDS detector of Thermo Scientific Co, Madison, WI, USA), XRD (D8 Advance System of Bruker's Co, BRUKER Corporation, Billerica, MA, USA), XPS (SCIENCE SES 2002, ScientaOmicron, Uppsala, Sweden), GDOES (Horiba Profiler 2, HORIBA Scientific, Palaiseau, France), and Confocal Laser Microscope (LEXT OLS 4000, Olympus Co, Tokyo, Japan), are described in detail in the Supplement (Section 1) and reference [25].

\section{Results}

\subsection{Scanning Electron Microscopy and Confocal Laser Scanning Microscopy Studies}

Scanning electron microscopy (SEM) and confocal laser scanning microscopy (CLSM) were used to view and describe the surfaces of porous samples after PEO treatment and to analyze their surface geometry structure. The topography of the surfaces is given by the three-dimensional (3D) parameters describing roughness $(S p, S v, S z, S a)$, as given by CLSM. The measurements of the surface geometrical structure were independently carried out on three planes in each point of the research plan.

Various electrolytes of orthophosphoric acid and orthophosphoric acid with the addition of the copper (II) nitrate (V) trihydrate in the following amounts: 10, 50, 200, 350, 500, and $650 \mathrm{~g} / \mathrm{dm}^{3}$ were used and the PEO processes were carried out under three voltages: 450, 550, and $650 \mathrm{~V}$ to determine the effect of voltage in the PEO process. All of the surfaces were viewed by SEM and CLSM and all of them are presented in Figures S1-S7 and the representative examples of those obtained in the electrolyte consisting of concentrated ( $85 \mathrm{wt} \%$ ) orthophosphoric acid without and with copper(II) nitrate trihydrate, which are presented below in Figures 1 and 2, respectively.
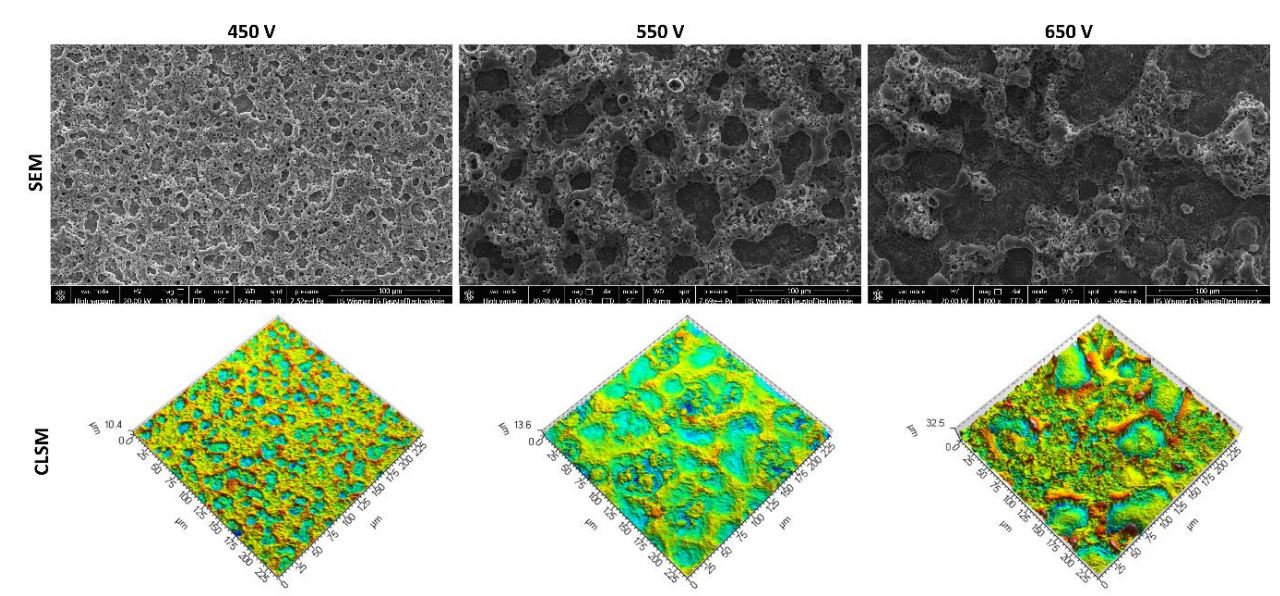

Figure 1. Exemplary scanning electron microscopy (SEM) images and three-dimensional (3D) maps obtained by using confocal laser scanning microscopy (CLSM) technique on the Plasma Electrolytic Oxidation (PEO) coatings fabricated with an electrolyte of pure concentrated orthophosphoric acid at voltages: $450 \mathrm{~V}, 550 \mathrm{~V}$, and $650 \mathrm{~V}$. 

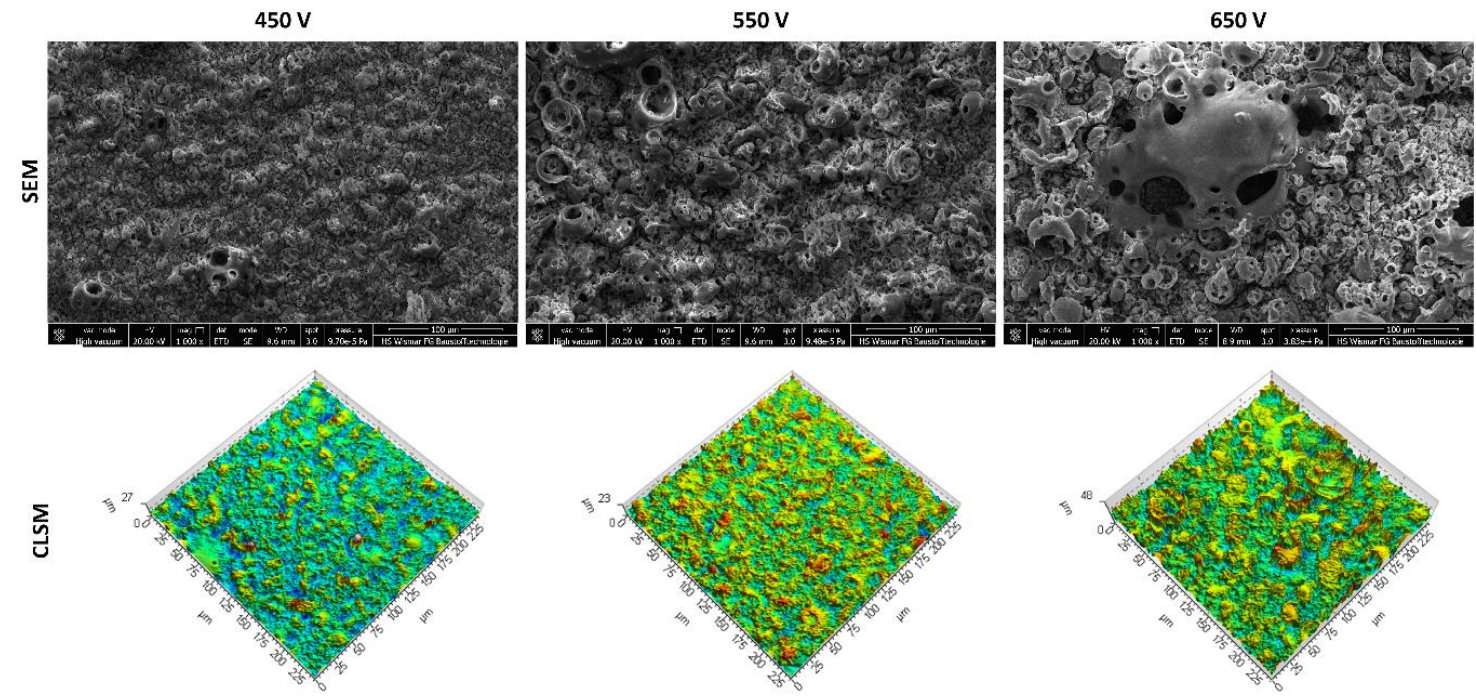

Figure 2. Exemplary SEM images and 3D maps obtained by using CLSM technique on the PEO coatings fabricated with an electrolyte of concentrated orthophosphoric acid with copper(II) nitrate trihydrate $\left(650 \mathrm{~g} / \mathrm{dm}^{3}\right)$ at voltages: $450 \mathrm{~V}, 550 \mathrm{~V}$, and $650 \mathrm{~V}$.

The SEM images of the coatings display the porous surfaces, on which the "pores-in-pores" may be observed. The coating obtained at $650 \mathrm{~V}$ shows the occurrence of cracks in its structure, as can be seen in Figure S1i,l, which is an undesired negative effect.

CLSM was utilized to study the influence of the process voltage on the change of the surface geometrical structure, with the results being presented by means of 3D maps. CLSM allowed for determining the parameters for the evaluation of the surface roughness; on the basis of these results, the parameters characterizing the surface topography, together with their basic statistical measures are determined, and shown in Table S1. The non-parametric ranks' sum test was carried out with the assumed significance level $\alpha=0.05$ to determine the significance of the effect of the voltage on the parameters for the evaluation of $3 \mathrm{D}$ surface roughness. As a result, it was stated that increasing the voltage from $450 \mathrm{~V}$ up to $550 \mathrm{~V}$ has no essential effect on the parameters $S p, S v$, and $S z$, at the assumed significance level $\alpha=0.05$. $S a$ is the only parameter that allows for differentiating the obtained surfaces. The average value of $S a$ for the surface obtained at the voltage $450 \mathrm{~V}$ is equal to $1.13 \mu \mathrm{m}$ and falls down to $1.03 \mu \mathrm{m}$ for the coating that was obtained at the voltage of $550 \mathrm{~V}$.

Between $550 \mathrm{~V}$ and $650 \mathrm{~V}$, however, all of the mentioned parameters show significant variation. The increase of voltage from $550 \mathrm{~V}$ up to $650 \mathrm{~V}$ resulted in an increase of the average value of the roughness parameters $S p$ (from $6.29 \mu \mathrm{m}$ to $15.20 \mu \mathrm{m}$ ), $S v$ (from $6.78 \mu \mathrm{m}$ to $16.37 \mu \mathrm{m}$ ), $S z$ (from $13.08 \mu \mathrm{m}$ to $31.54 \mu \mathrm{m}$ ), and $S a$ (from $1.03 \mu \mathrm{m}$ to $2.87 \mu \mathrm{m}$ ).

In Figure S2, the SEM images and 3D maps of the surface geometrical structure, characterizing the surface of coatings that were obtained in an electrolyte consisting of $10 \mathrm{~g}$ of the copper(II) nitrate(V) trihydrate and $1 \mathrm{dm}^{3}$ of orthophosphoric acid, are shown. Alike the coatings that were obtained in concentrated orthophosphoric acid, without any salt used, the increase of the voltage in the PEO process from $450 \mathrm{~V}$ to $650 \mathrm{~V}$ resulted in the change of pores stereometry, which can be observed in Figure S2. Each of the obtained surfaces is characteristic with the "pores-in-pores", which are shown in Figure S2g-l. The 3D surfaces, which were obtained on the basis of CLSM, as presented in Figure S2m-o, confirm the results of SEM imaging. From the CLSM results, the parameters for the evaluation of the 3D surface roughness were determined, with the magnitudes and statistical measures that are given in Table S2. The increase of voltage in the PEO process from $450 \mathrm{~V}$ to $550 \mathrm{~V}$ resulted in the increase of average values of all parameters $S p$ (from $6.24 \mu \mathrm{m}$ to $12.57 \mu \mathrm{m}$ ), $S v$ (from $5.51 \mu \mathrm{m}$ to $12.37 \mu \mathrm{m}$ ), $S z$ (from $11.75 \mu \mathrm{m}$ to $24.94 \mu \mathrm{m}$ ), and $S a$ (from 1.00 to $2.35 \mu \mathrm{m}$ ). This trend continues when the voltage increases from $550 \mathrm{~V}$ to $650 \mathrm{~V}$. The surfaces of porous coatings that were obtained in the 
electrolyte containing $50 \mathrm{~g} \mathrm{Cu}\left(\mathrm{NO}_{3}\right)_{2} \cdot 3 \mathrm{H}_{2} \mathrm{O}$ in $1 \mathrm{dm}^{3} \mathrm{H}_{3} \mathrm{PO}_{4}$ at the voltages of $450 \mathrm{~V}$, $550 \mathrm{~V}$, and $650 \mathrm{~V}$ are illustrated by SEM images (Figure S3a-1), and the CLSM results (Figure S3m-o). In the SEM images that are presented in Figure S3g-l, one might observe the occurrence of "pores-in-pores" characteristic phenomena of the obtained surface. The 3D surface roughness parameters have been assigned and are presented in Table S3 and studied for the significance, as previously explained. An increase of the voltage of the PEO process from $450 \mathrm{~V}$ up to $550 \mathrm{~V}$ resulted in the increase of average values of all the roughness parameters $S p$ (from $4.41 \mu \mathrm{m}$ to $13.44 \mu \mathrm{m}$ ), $S v$ (from $5.31 \mu \mathrm{m}$ to $16.22 \mu \mathrm{m}$ ), $S z$ (from $9.72 \mu \mathrm{m}$ to $29.67 \mu \mathrm{m}$ ), and $S a$ (from $0.99 \mu \mathrm{m}$ to $2.87 \mu \mathrm{m}$ ).

However, when the voltages ranged from $550 \mathrm{~V}$ to $650 \mathrm{~V}$, we observe a significant change of $S v$ and $S a$, with their average value getting down from $16.22 \mu \mathrm{m}$ down to $12.00 \mu \mathrm{m}$ for $S v$, and from $2.87 \mu \mathrm{m}$ to $2.00 \mu \mathrm{m}$ for $S a$.

The next step in the evaluation of the effect of the content of copper(II) nitrate(V) trihydrate in orthophosphoric acid and the voltage on the surface geometry of the porous coatings was pursued with electrolyte containing $200 \mathrm{~g} \mathrm{Cu}\left(\mathrm{NO}_{3}\right) \cdot 3 \mathrm{H}_{2} \mathrm{O}$ in $1 \mathrm{dm}^{3} \mathrm{H}_{3} \mathrm{PO}_{4}$ at voltages of $450 \mathrm{~V}, 550 \mathrm{~V}$, and 650 $\mathrm{V}$. The results obtained in the form of SEM images and 3D models have been correlated in Figure S4. Similarly to the cases described before, changes in the development of the porous surface are linked to the increase of voltage for the PEO process, with the results that are presented in Figure S4a-e. At $650 \mathrm{~V}$, inside the pores visible on the surface of the coating, there are "pores-in-pores" clearly visible. This phenomenon is more pronounced than in the case of coatings obtained in electrolytes with lower contents of salt, as presented in Figure S4i. The surfaces of the obtained coatings in this case, at each of the voltages applied, feature more developed stereometric structure, as shown in Figure S4j-1. The observed changes in the pictures that were obtained by SEM technique have been confirmed by the results obtained while the using CLSM technique, as presented in Figure S4m-o. Table S4 summarizes the obtained results.

The increase in voltages from $450 \mathrm{~V}$ to $550 \mathrm{~V}$ resulted in an essential growth of the average values of all parameters, at the assumed significance level of $\alpha=0.05$. However, from $550 \mathrm{~V}$ to $650 \mathrm{~V}$, only the $S z$ parameter shows a significant increase (again at the assumed significance level $\alpha=0.05$ ). Figure S5 displays the surfaces of the porous coatings obtained in the electrolyte consisting of $350 \mathrm{~g}$ of copper(II) nitrate(V) trihydrate dissolved in $1 \mathrm{dm}^{3}$ of orthophosphoric acid at voltages of $450 \mathrm{~V}, 550 \mathrm{~V}$, and $650 \mathrm{~V}$. Based on the analysis of SEM images, one may state that pores occurring in the coatings that were obtained under the voltages of $450 \mathrm{~V}$, and $550 \mathrm{~V}$ (Figure S5a-b) are characteristic with a different stereometry, whereas the surfaces obtained at voltages of $550 \mathrm{~V}$ and $650 \mathrm{~V}$ may be qualified as very similar, as seen in Figure S5n-o. The CLSM measurements for quantitatively describing the parameters to evaluate the surface roughness are shown in Figure S5m-n, and collected in Table S5. The significance test displays a great effect of voltage change from $450 \mathrm{~V}$ to $550 \mathrm{~V}$ for all parameters $S p, S v, S z$, and $S a$ with the average values increasing by $9.32 \mu \mathrm{m}$ for $S p, 12.20 \mu \mathrm{m}$ for $S v, 21.53 \mu \mathrm{m}$ for $S z$, and $1.50 \mu \mathrm{m}$ for $S a$. However, the same tests for voltages between $550 \mathrm{~V}$ and $650 \mathrm{~V}$ do not reveal significant differences.

The following results that are presented in Figure S6 concern the PEO coatings obtained in an electrolyte containing $500 \mathrm{~g} \mathrm{Cu}\left(\mathrm{NO}_{3}\right)_{2} \cdot 3 \mathrm{H}_{2} \mathrm{O}$ in $1 \mathrm{dm}^{3} \mathrm{H}_{3} \mathrm{PO}_{4}$ at voltages of $450 \mathrm{~V}, 550 \mathrm{~V}$, and $650 \mathrm{~V}$. The increase in the amount of salt leads to coatings that have a different outer structure as compared to the ones previously observed and the SEM images do not univocally allow for differentiating the surfaces, as seen in Figure S6g-l. For this reason, to describe the surface topography, the roughness parameters to evaluate 3D surfaces, determined on the basis of the performed CLSM studies, were used. Table S6 collects the determined parameters, together with their basic statistical measures and significance. The change of voltage from $450 \mathrm{~V}$ to $550 \mathrm{~V}$ resulted in a substantial increase of values of all parameters $S p$ (from $8.66 \mu \mathrm{m}$ to $14.20 \mu \mathrm{m}$ ), $S v$ (from $8.70 \mu \mathrm{m}$ to $15.96 \mu \mathrm{m}$ ), $S z$ (from $17.36 \mu \mathrm{m}$ to $30.16 \mu \mathrm{m}$ ), and $S a$ (from $1,33 \mu \mathrm{m}$ to $2.32 \mu \mathrm{m}$ ). The significance studies of the effect of voltage change of the PEO process from $550 \mathrm{~V}$ to $650 \mathrm{~V}$ on the parameters serving to evaluate the 3D surface roughness have been also performed, and some parameters feature a substantial growth 
$S p$ (from $14.20 \mu \mathrm{m}$ to $22.61 \mu \mathrm{m}$ ), $S v$ (from $15.96 \mu \mathrm{m}$ to $22.57 \mu \mathrm{m}$ ), and $S a$ (from $2.32 \mu \mathrm{m}$ to $3.42 \mu \mathrm{m}$ ), whereas $S z$ does not change significantly.

The highest content of copper(II) nitrate(V) trihydrate dissolved in $1 \mathrm{dm}^{3}$ of orthophosphoric acid, for which it was possible to obtain the porous PEO coatings at all voltages $450 \mathrm{~V}, 550 \mathrm{~V}$, and $650 \mathrm{~V}$, is equal to $650 \mathrm{~g}$. The study results of the surfaces that were obtained with such amount of salt, have been placed in Figure S7 and partly in Figure 2 of this paper. Table S7 collects the 3D surface roughness parameters. No significant differences occur between $450 \mathrm{~V}$ and $550 \mathrm{~V}$, but between $550 \mathrm{~V}$ and $650 \mathrm{~V}$ there are essential differences for $S p$ (increase of the average value from $12.74 \mu \mathrm{m}$ to $20.58 \mu \mathrm{m}$ ) and $S a$ (increase of the average value from $2.09 \mu \mathrm{m}$ to $3.59 \mu \mathrm{m}$ ), whereas $S v$ and $S z$ do not statistically differ.

\subsection{EDS Studies}

For a statistical quantitative description of the elementary composition of the PEO coatings that were obtained in the electrolyte made of concentrated orthophosphoric acid and copper(II) nitrate(V) trihydrate, the EDS technique was used. In order to determine the atomic ratio $\mathrm{Cu} / \mathrm{P}$, a study plan taking into account the detection/quantification limit values of copper by the EDS method was employed and quantitative EDS studies were carried out for the PEO coatings that were obtained in electrolytes containing significant amount of $\mathrm{Cu}\left(\mathrm{NO}_{3}\right)_{2} \cdot 3 \mathrm{H}_{2} \mathrm{O}$, namely $200 \mathrm{~g}, 350 \mathrm{~g}$, $500 \mathrm{~g}$, and $650 \mathrm{~g}$ in $1 \mathrm{dm}^{3}$ $\mathrm{H}_{3} \mathrm{PO}_{4}$ at all voltages $450 \mathrm{~V}, 550 \mathrm{~V}$, and $650 \mathrm{~V}$.

All of the EDS studies were carried out on ten surfaces of the titanium samples after the PEO process, with ten repetitions on each of the surfaces with the magnification used equaling $500 \times$, resulting, in total, 100 repetitions for one point of the study plan. Figure 3 provides an exemplary EDS spectrum.

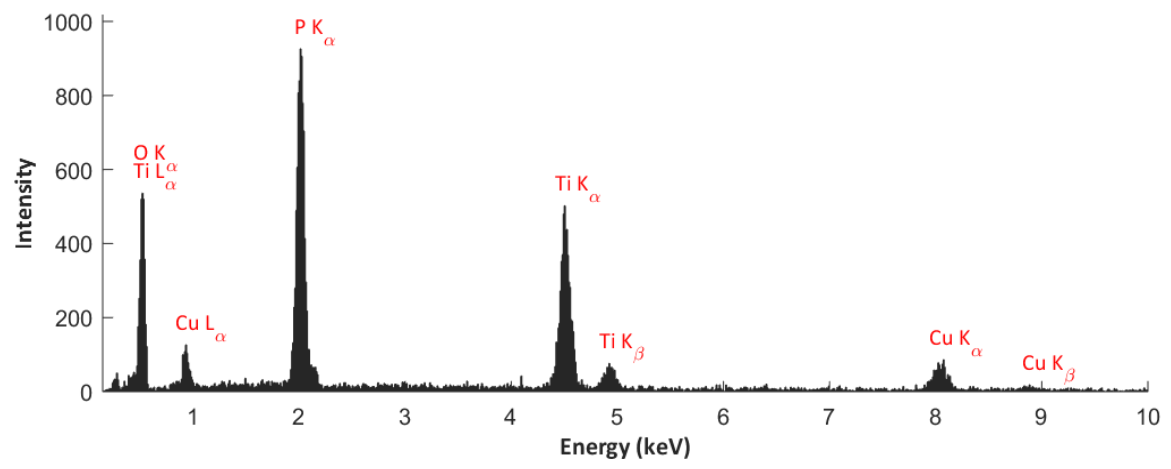

Figure 3. Example of EDS spectrum obtained on the surface of a titanium sample after the PEO treatment in the electrolyte containing $500 \mathrm{~g} \mathrm{Cu}\left(\mathrm{NO}_{3}\right)_{2} \cdot 3 \mathrm{H}_{2} \mathrm{O}$ in $1 \mathrm{dm}^{3} \mathrm{H}_{3} \mathrm{PO}_{4}$ at the voltage of $550 \mathrm{~V}$.

Histograms and fitted normal distributions, as well as basic statistical measures of the determined atomic ratios $\mathrm{Cu} / \mathrm{P}$, have been established to illustrate the effect of the voltage change on the parameter $\mathrm{Cu} / \mathrm{P}$ and they are shown in the following Figure 4 (coatings obtained in the electrolyte containing $200 \mathrm{~g} \mathrm{Cu}\left(\mathrm{NO}_{3}\right)_{2} \cdot 3 \mathrm{H}_{2} \mathrm{O}$ in $1 \mathrm{dm}^{3} \mathrm{H}_{3} \mathrm{PO}_{4}$ ), Figure 5 (coatings obtained in the electrolyte containing $350 \mathrm{~g}$ $\mathrm{Cu}\left(\mathrm{NO}_{3}\right)_{2} \cdot 3 \mathrm{H}_{2} \mathrm{O}$ in $1 \mathrm{dm}^{3} \mathrm{H}_{3} \mathrm{PO}_{4}$ ), and Figure 6 (coatings obtained in the electrolyte containing $500 \mathrm{~g}$ $\mathrm{Cu}\left(\mathrm{NO}_{3}\right)_{2} \cdot 3 \mathrm{H}_{2} \mathrm{O}$ in $1 \mathrm{dm}^{3} \mathrm{H}_{3} \mathrm{PO}_{4}$ ), Figure 7 (coatings obtained in the electrolyte containing $650 \mathrm{~g}$ $\mathrm{Cu}\left(\mathrm{NO}_{3}\right)_{2} \cdot 3 \mathrm{H}_{2} \mathrm{O}$ in $\left.1 \mathrm{dm}^{3} \mathrm{H}_{3} \mathrm{PO}_{4}\right)$. 
(a)

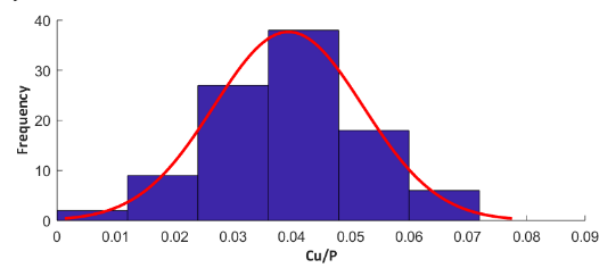

(c)

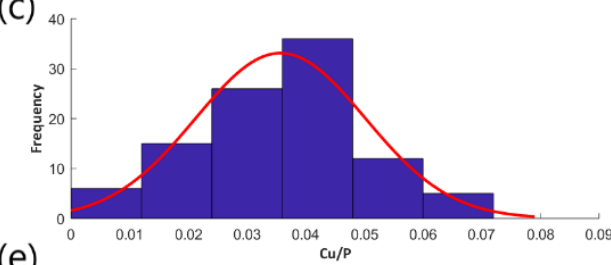

(e)

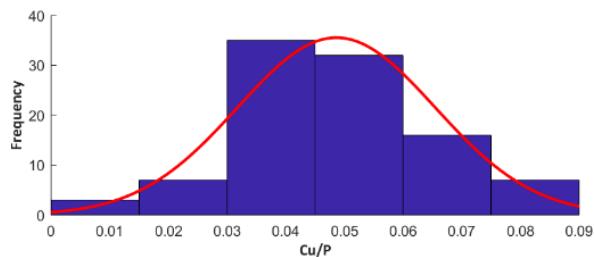

(b)

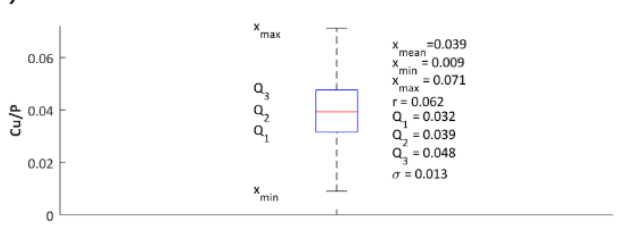

(d)

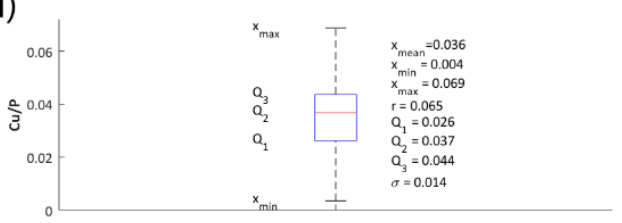

(f)

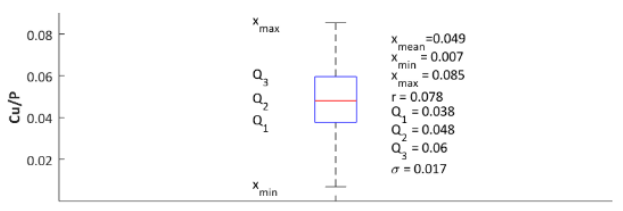

Figure 4. Histograms of the atomic ratio $\mathrm{Cu} / \mathrm{P}(\mathbf{a}, \mathbf{c}, \mathbf{e})$, box plots and basic statistical measures $(\mathbf{b}, \mathbf{d}, \mathbf{f})$ for the coatings that were obtained in the electrolyte consisting of $200 \mathrm{~g} / \mathrm{dm}^{3}$ of $\mathrm{Cu}\left(\mathrm{NO}_{3}\right)_{2} \cdot 3 \mathrm{H}_{2} \mathrm{O}$ at the voltages $450 \mathrm{~V}(\mathbf{a}, \mathbf{b}), 550 \mathrm{~V}(\mathbf{c}, \mathbf{d})$, and $650 \mathrm{~V}(\mathbf{e}, \mathbf{f})$.

(a)
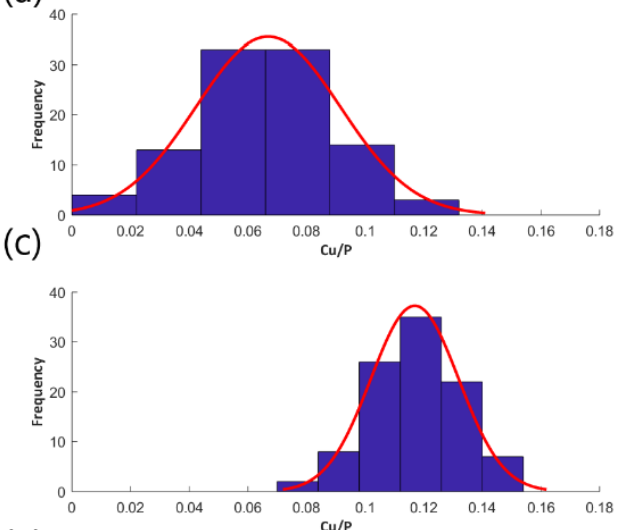

(e)

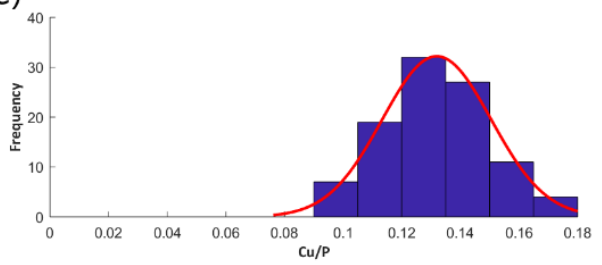

(b)

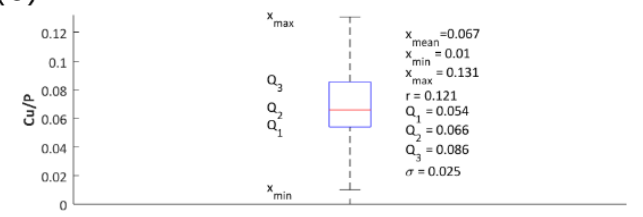

(d)

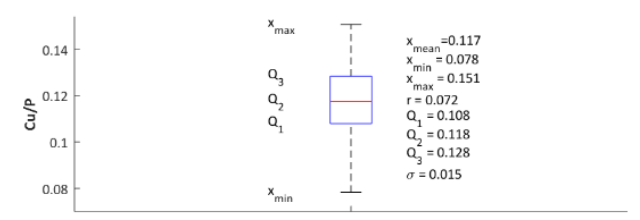

(f)

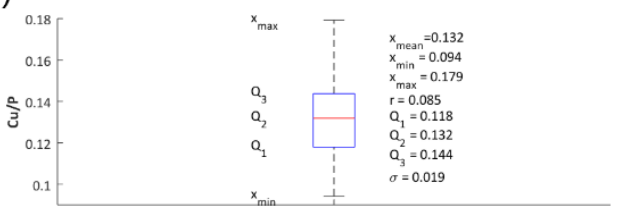

Figure 5. Histograms of the atomic ratio $\mathrm{Cu} / \mathrm{P}(\mathbf{a}, \mathbf{c}, \mathbf{e})$, box plots and basic statistical measures $(\mathbf{b}, \mathbf{d}, \mathbf{f})$ for the coatings obtained in the electrolyte consisting of $350 \mathrm{~g} / \mathrm{dm}^{3}$ of $\mathrm{Cu}(\mathrm{NO} 3)_{2} \cdot 3 \mathrm{H}_{2} \mathrm{O}$ at the voltages $450 \mathrm{~V}(\mathbf{a}, \mathbf{b}), 550 \mathrm{~V}(\mathbf{c}, \mathbf{d})$, and $650 \mathrm{~V}(\mathbf{e}, \mathbf{f})$. 
(a)

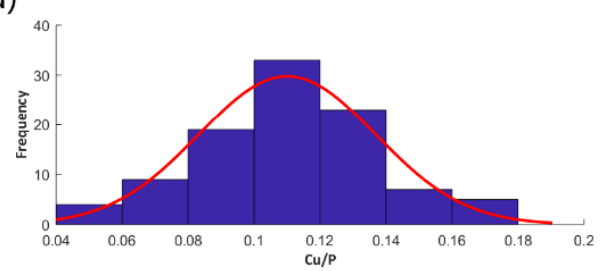

(c)

(e)
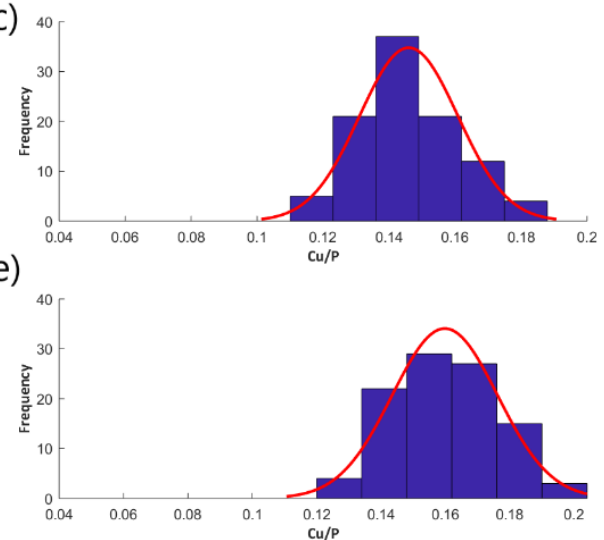

(b)

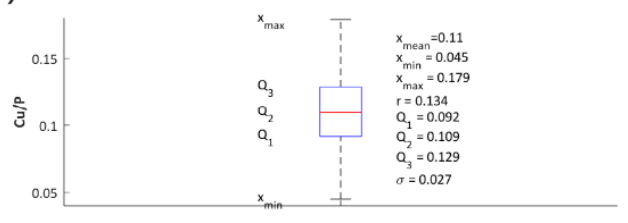

(d)

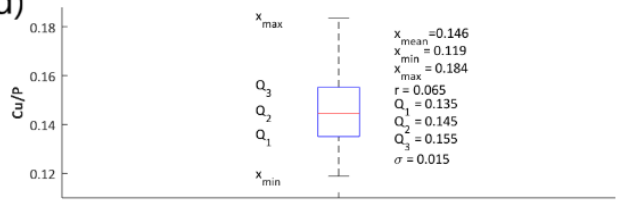

(f)

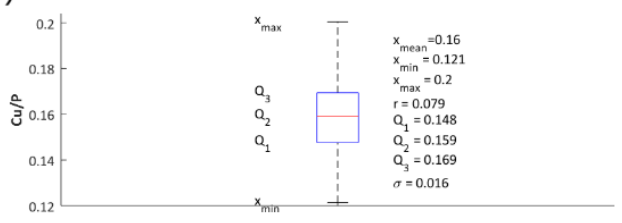

Figure 6. Histograms of the atomic ratio $\mathrm{Cu} / \mathrm{P}(\mathbf{a}, \mathbf{c}, \mathbf{e})$, box plots and the basic statistical measures $(\mathbf{b}, \mathbf{d}, \mathbf{f})$ for the coatings obtained in the electrolyte consisting of $\mathrm{Cu}\left(\mathrm{NO}_{3}\right)_{2} \cdot 3 \mathrm{H}_{2} \mathrm{O}$ amounting for $500 \mathrm{~g} / \mathrm{dm}^{3}$ at the voltages $450 \mathrm{~V}(\mathbf{a}, \mathbf{b}), 550 \mathrm{~V}(\mathbf{c}, \mathbf{d})$, and $650 \mathrm{~V}(\mathbf{e}, \mathbf{f})$.

(a)

(c)

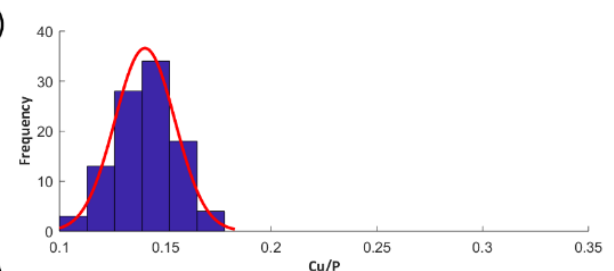

(e)
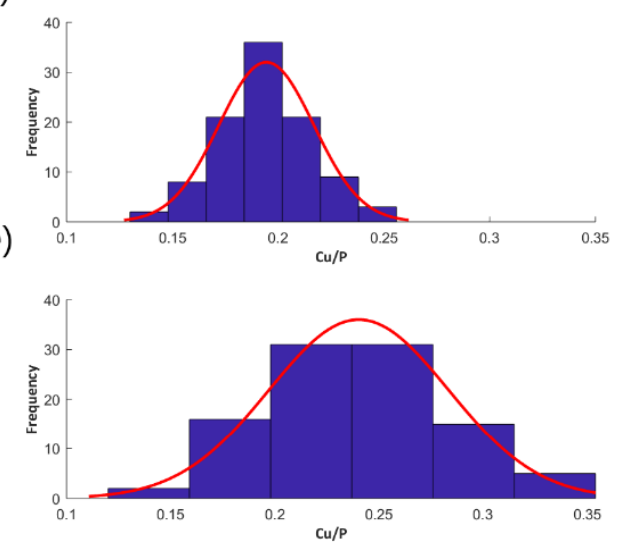

(b)

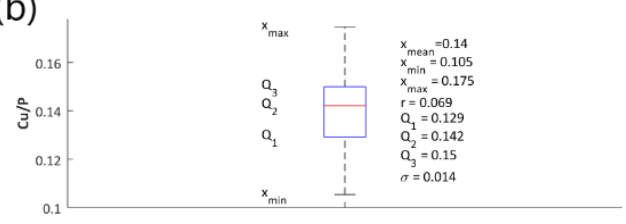

(d)

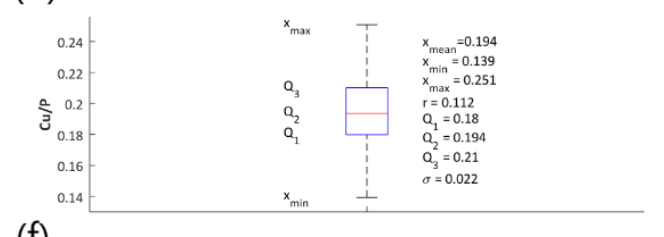

(f)

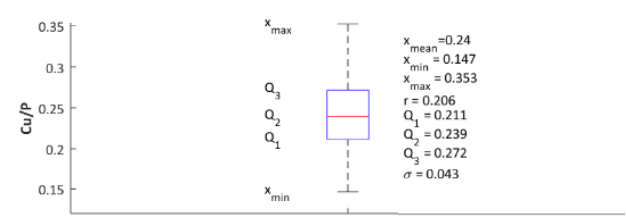

Figure 7. Histograms of the atomic ratio $\mathrm{Cu} / \mathrm{P}(\mathbf{a}, \mathbf{c}, \mathbf{e})$, box plots and basic statistical measures $(\mathbf{b}, \mathbf{d}, \mathbf{f})$ for the coatings obtained in the electrolyte consisting of $650 \mathrm{~g} / \mathrm{dm}^{3}$ of $\mathrm{Cu}\left(\mathrm{NO}_{3}\right)_{2} \cdot 3 \mathrm{H}_{2} \mathrm{O}$ at the voltages $450 \mathrm{~V}(\mathbf{a}, \mathbf{b}), 550 \mathrm{~V}(\mathbf{c}, \mathbf{d})$, and $650 \mathrm{~V}(\mathbf{e}, \mathbf{f})$.

Figure $4 a, c, e$, Figure 5a,c,e, Figure 6a,c,e, and Figure 7a,c,e represent the histograms with the normal distributions (red lines) for each of the voltages $450 \mathrm{~V}, 550 \mathrm{~V}$, and $650 \mathrm{~V}$, and Figure $4 \mathrm{~b}, \mathrm{~d}, \mathrm{f}$, Figure $5 b, d, f$, Figure $6 b, d, f$, and Figure $7 b, d, f$ show the box plots with statistical measures for the corresponding voltages. 


\subsection{XPS Studies}

XPS studies were carried out, with the qualitative and quantitative analyses of all the XPS data presented in Figures S8-S16 to describe the chemical composition of the top 10-nm surface layer of the PEO coatings; an exemplary one with maximum amount of copper inside has been presented below, as in Figure 8.
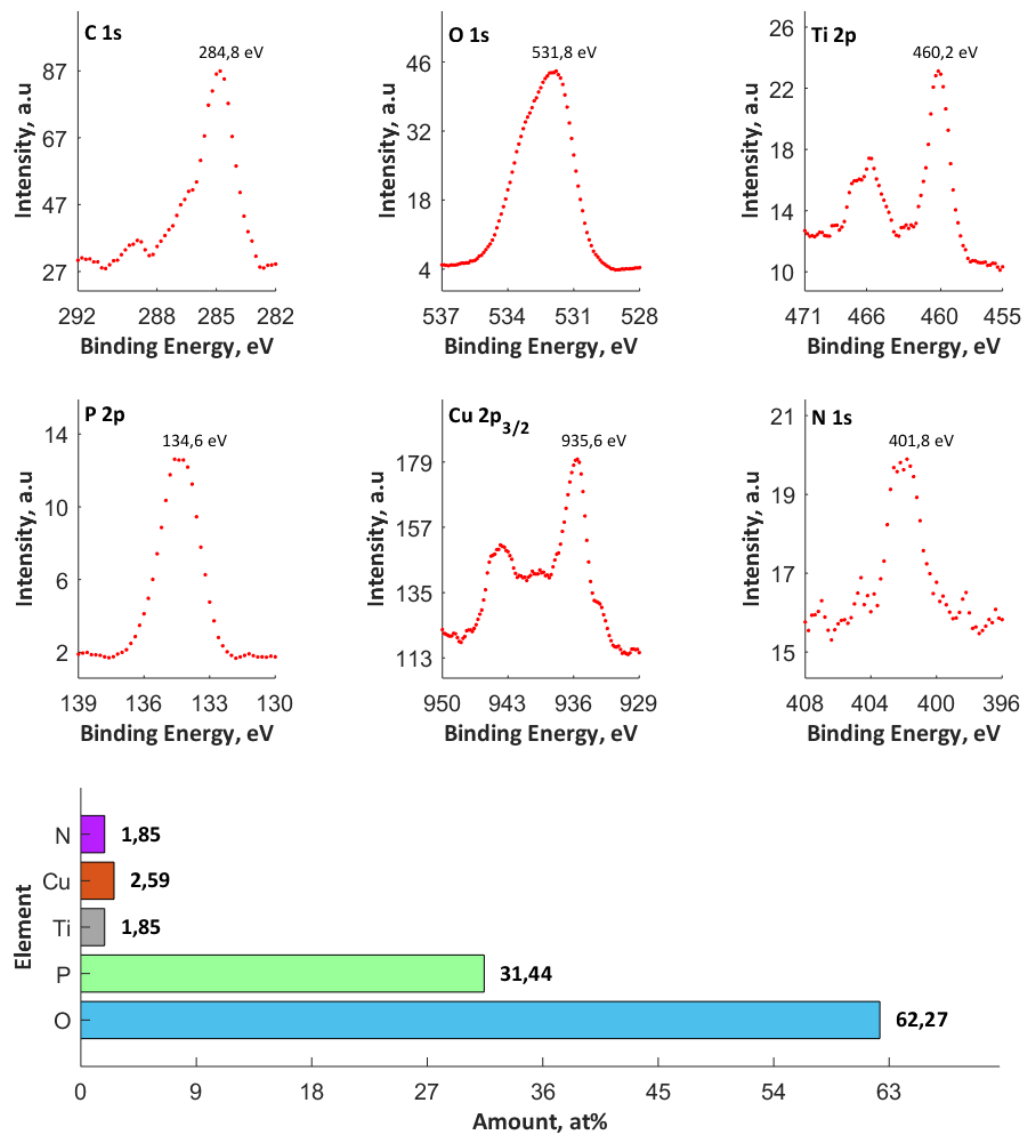

Figure 8. XPS quantitative analysis of the chemical composition of surface layers of an exemplary PEO coating containing maximum amount of copper inside $\left(650 \mathrm{~g} / \mathrm{dm}^{3} \mid 650 \mathrm{~V}\right)$.

The compounds of titanium and copper are present, as proved by the binding energies in the ranges of 459.4-460.8 eV $\left(\mathrm{Ti}^{4+}\right)$ and $932.2-936.8 \mathrm{eV}\left(\mathrm{Cu}^{2+}\right.$, and/or $\left.\mathrm{Cu}^{+}\right)$. On the other hand, the analyses of spectra of phosphorus $\mathrm{P} 2 \mathrm{p}(133.6-135.4 \mathrm{eV})$ and oxygen $\mathrm{O} 1 \mathrm{~s}(531.1-532.7 \mathrm{eV})$ indicate the presence of phosphates, and/or diphosphates, and/or phosphates groups. Moreover, the position of the highest peak value in the spectrum of $\mathrm{O} 1 \mathrm{~s}$ does not exclude the presence of hydroxyl groups, and metal oxides in the surface layer. The hydroxyl groups may be connected in the coating in the form of hydroxyphosphates and/or hydroxyoxides.

The XPS calculations reveal the occurrence of non-stoichiometric phosphate groups. The analyses of C 1s $(284.8 \mathrm{eV})$ and N 1s (399.6-403.4 eV) spectra indicate the presence of both carbon and nitrogen that result from atmospheric contamination and possibly introduced during the preparation of the samples. The $\mathrm{N} 1 \mathrm{~s}$ spectrum might also indicate the presence of ammonia compounds. The increase of the amount of the copper(II) nitrate(V) in the electrolyte from 50 to $500 \mathrm{~g} / \mathrm{dm}^{3}$ at a constant voltage $550 \mathrm{~V}$ resulted in the increase of the amount of copper built in the structure of coating from 0.24 to 1.38 at $\%$ (over five-fold growth), whereas, at a constant amount of salt in the electrolyte $\left(500 \mathrm{~g} / \mathrm{dm}^{3}\right)$, a change in the process voltage from $450 \mathrm{~V}$ to $650 \mathrm{~V}$ results in an increase of the amount of copper from 1.18 to $1.81 \mathrm{at} \%$ (over 1.5-fold growth). If the amount of salt in the solution is up to $650 \mathrm{~g} / \mathrm{dm}^{3}$, 
the same increase of voltage from $450 \mathrm{~V}$ to $650 \mathrm{~V}$ resulted in an amount of copper in the coating to reach $2.33-2.59$ at $\%$. In addition, the ratio $\mathrm{Cu} / \mathrm{P}$ was in the interval of 0.009 to 0.082 .

\subsection{XRD Studies}

XRD studies were also carried out in agreement with the assumed study plan, and the results have been displayed in Figures S17-S24. The coatings obtained in the electrolytes with $10 \mathrm{~g} / \mathrm{dm}^{3}$ $\mathrm{Cu}\left(\mathrm{NO}_{3}\right)_{2} \cdot 3 \mathrm{H}_{2} \mathrm{O}$ (Figure S17) and $50 \mathrm{~g} / \mathrm{dm}^{3}$ (Figure 9 in the paper) at a voltage of $550 \mathrm{~V}$, containing in their structure the titanium oxides $\left(\mathrm{TiO}_{2}\right.$ (anatase), $\left.\mathrm{TiO}_{3}, \mathrm{Ti}_{0,73} \mathrm{O}_{0,91}\right)$ and diphosphate( $\mathrm{V}$ ) of titanium(IV) $\left(\mathrm{TiP}_{2} \mathrm{O}_{7}\right)$, in the crystal form.

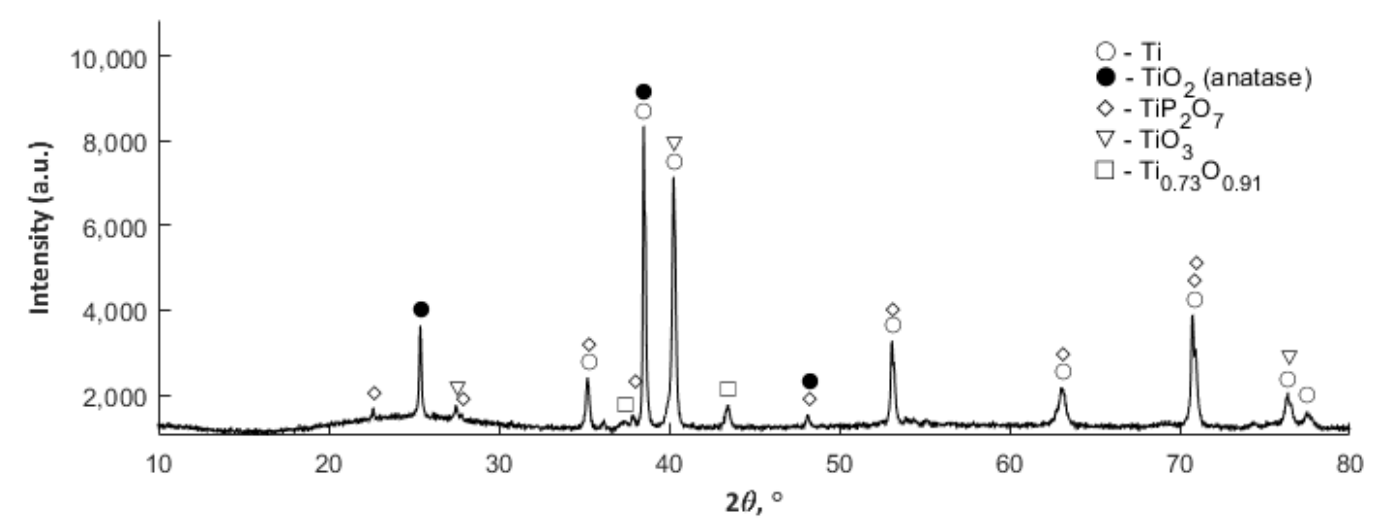

Figure 9. XRD diffractogram obtained for the PEO coating fabricated in the electrolyte consisting of orthophosphoric acid and copper(II) nitrate(V) trihydrate at concentration $50 \mathrm{~g} / \mathrm{dm}^{3}$ and voltage of $550 \mathrm{~V}$.

Increasing the content of salt $\mathrm{Cu}\left(\mathrm{NO}_{3}\right)_{2} \cdot 3 \mathrm{H}_{2} \mathrm{O}$ from 10 to $50 \mathrm{~g} / \mathrm{dm}^{3}$ resulted in an increase of the observed halo $2 \theta$ in the range of $20^{\circ}$ to $30^{\circ}$, which is most probably connected with the formation of an amorphous or nano-crystalline phase. The coatings that were obtained in electrolytes with $200 \mathrm{~g}$ $\mathrm{Cu}\left(\mathrm{NO}_{3}\right)_{2} \cdot 3 \mathrm{H}_{2} \mathrm{O}$ (Figure S19) and $350 \mathrm{~g} \mathrm{Cu}\left(\mathrm{NO}_{3}\right)_{2} \cdot 3 \mathrm{H}_{2} \mathrm{O}$ (Figure S20) in $1 \mathrm{dm}^{3} \mathrm{H}_{3} \mathrm{PO}_{4}$ at a voltage of $550 \mathrm{~V}$ show the presence of anatase $\left(\mathrm{TiO}_{2}\right)$ and titanium(IV) diphosphate $(\mathrm{V})\left(\mathrm{TiP}_{2} \mathrm{O}_{7}\right)$; here also the increase of the content of copper(II) nitrate(V) trihydrate in the electrolyte leads to an increase of the intensity of the observed halo $2 \theta$ in the range from $20^{\circ}$ to $30^{\circ}$.

The XRD diffractogram that was obtained for the PEO coating fabricated in the electrolyte containing $500 \mathrm{~g} / \mathrm{dm}^{3} \mathrm{Cu}\left(\mathrm{NO}_{3}\right)_{2} \cdot 3 \mathrm{H}_{2} \mathrm{O}$ at the voltage of $550 \mathrm{~V}$ (Figure S21) indicated the presence of titanium only with a halo for $2 \theta$ in the range from $20^{\circ}$ to $30^{\circ}$. In these conditions, the PEO coating is most probably nano-structured or it has an amorphous structure.

We have decided to vary the PEO process potential/voltage from $450 \mathrm{~V}$ to $650 \mathrm{~V}$, keeping a constant chemical composition of the electrolyte $\left(500 \mathrm{~g} \mathrm{Cu}\left(\mathrm{NO}_{3}\right)_{2} \cdot 3 \mathrm{H}_{2} \mathrm{O}\right.$ in $\left.1 \mathrm{dm}^{3} \mathrm{H}_{3} \mathrm{PO}_{4}\right)$, in order to study the effect of the voltage on the formation of a crystalline phase identifiable by XRD. The XRD results proved that the decrease of the potential/voltage of the PEO process from 550 to $450 \mathrm{~V}$ leads to the detection in the crystalline phase of anatase $\left(\mathrm{TiO}_{2}\right)$ and titanium(IV) and titanium(IV) diphosphate(V) $\left(\mathrm{TiP}_{2} \mathrm{O}_{7}\right)$, $\left(\mathrm{TiP}_{2} \mathrm{O}_{7}\right)$, which are displayed in Figure S22, whereas the increase of voltage up to $650 \mathrm{~V}$ resulted in the recording of a crystalline phase, consisting of the anatase $\left(\mathrm{TiO}_{2}\right)$ and titanium(IV) diphosphate $(\mathrm{V})$ $\left(\mathrm{TiP}_{2} \mathrm{O}_{7}\right.$ ), (Figure S23). The increase of the contents of $\mathrm{Cu}\left(\mathrm{NO}_{3}\right)_{2} \cdot 3 \mathrm{H}_{2} \mathrm{O}$ in the electrolyte up to $650 \mathrm{~g} / \mathrm{dm}^{3}$ at a fixed voltage $550 \mathrm{~V}$ resulted in identifying the anatase $\left(\mathrm{TiO}_{2}\right)$ and the compounds of copper: $\alpha-$ copper(II) diphosphate(V) $\left(\mathrm{Cu}_{2} \mathrm{P}_{2} \mathrm{O}_{7}\right)$ and copper(II) phosphate(V) $\left(\mathrm{Cu}_{3}\left(\mathrm{PO}_{4}\right)_{2}\right)$, as displayed below, as in Figure 10. 


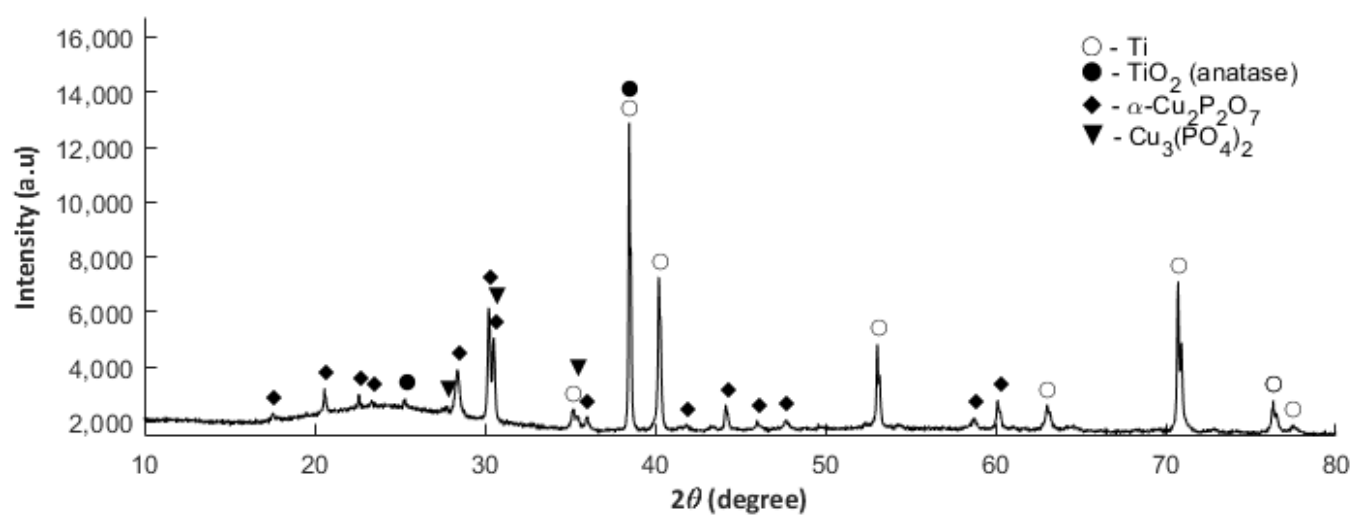

Figure 10. XRD diffractogram obtained for the PEO coating fabricated in the electrolyte consisting of orthophosphoric acid and the copper(II) nitrate(V) trihydrate of concentration $650 \mathrm{~g} / \mathrm{dm}^{3}$ and voltage of $550 \mathrm{~V}$.

\subsection{GDOES Studies}

The Glow-Discharge Optical Emission Spectroscopy (GDOES) technique was used to determine the effect of the applied voltage in the PEO process on the thicknesses of the obtained coatings and the distribution of particular elements as a function of depth. The GDOES measurements were carried out on the samples after PEO treatment with an electrolyte containing $350 \mathrm{~g}$ of the copper(II) nitrate(V) trihydrate in $1 \mathrm{dm}^{3}$ of orthophosphoric ( $85 \mathrm{wt} \%$ ) acid and at voltages of $450 \mathrm{~V}, 550 \mathrm{~V}$, and $650 \mathrm{~V}$, and the results are presented in Figure 11 (450 V), Figure 12 (550 V), and Figure 13 (650 V).

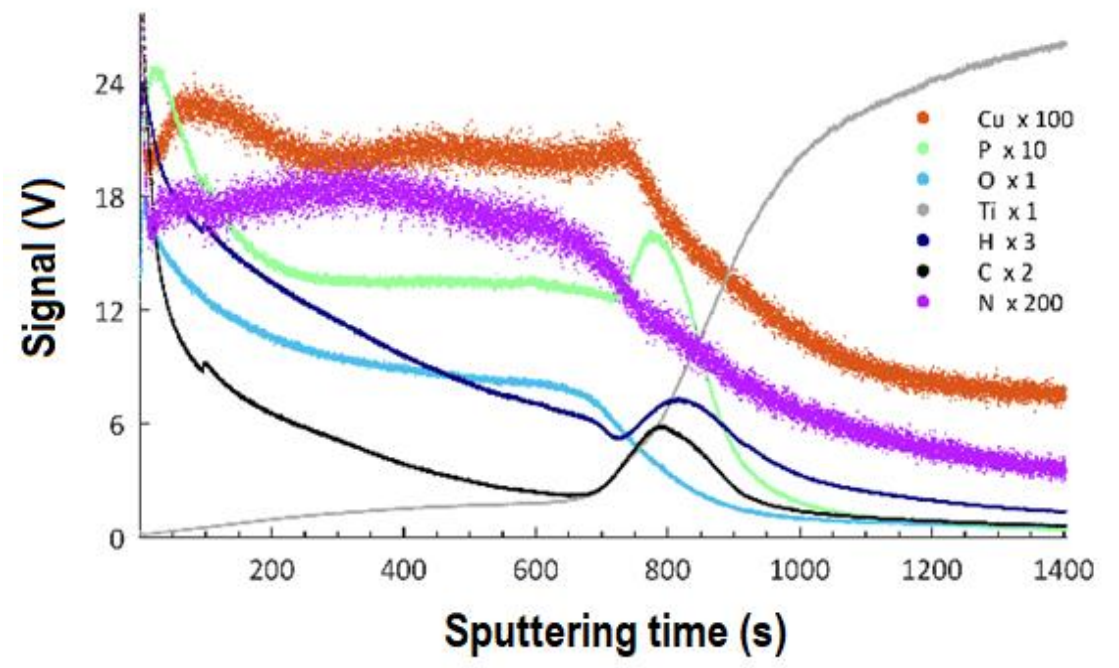

Figure 11. GDOES depth profile of coating obtained in the electrolyte containing $350 \mathrm{~g} / \mathrm{dm}^{3}$ of $\mathrm{Cu}(\mathrm{NO})_{3} \cdot 3 \mathrm{H}_{2} \mathrm{O}$ with $\mathrm{PEO}$ voltage of $450 \mathrm{~V}$. The elements $\mathrm{Cu}, \mathrm{P}, \mathrm{O}, \mathrm{Ti}, \mathrm{H}, \mathrm{C}$, and $\mathrm{N}$ may be present in the coatings or result from adsorbed contamination from the atmosphere or cleaning procedure.

The results allow for stating that the coatings obtained at all voltages may be described as three consecutive layers: a porous layer, a semi-porous layer, and a transient layer. The outer porous layer is enriched with copper, phosphorus, oxygen, hydrogen, carbon, and nitrogen, but depleted in titanium. In each of the analyzed coatings, the characteristic feature of this outer layer is the occurrence of a global maximum for the signals of: copper, phosphorus, oxygen, hydrogen, carbon, and nitrogen. The determined thickness of the porous layers for the samples that were obtained at the voltages of $450 \mathrm{~V}, 550 \mathrm{~V}$, and $650 \mathrm{~V}$ was, as follows: $1.9 \mu \mathrm{m}$ (220 s of GDOES etching time), $3.5 \mu \mathrm{m}$ (400 s of GDOES etching time), and $4.3 \mu \mathrm{m}$ (500 s of GDOES etching time). The porous layer is the thinner one of the three considered layers of the PEO coating. The next layer, placed under the porous one, is semi-porous 
and featured by signals of phosphorus, oxygen, nitrogen, hydrogen, and carbon close to a plateau. The copper signal for this layer (in the case of a coating fabricated at the voltage of $450 \mathrm{~V}$ ) is almost constant in depth, whereas a decreasing trend for $\mathrm{Cu}$ is observed for higher voltages $(550 \mathrm{~V}, 650 \mathrm{~V})$.

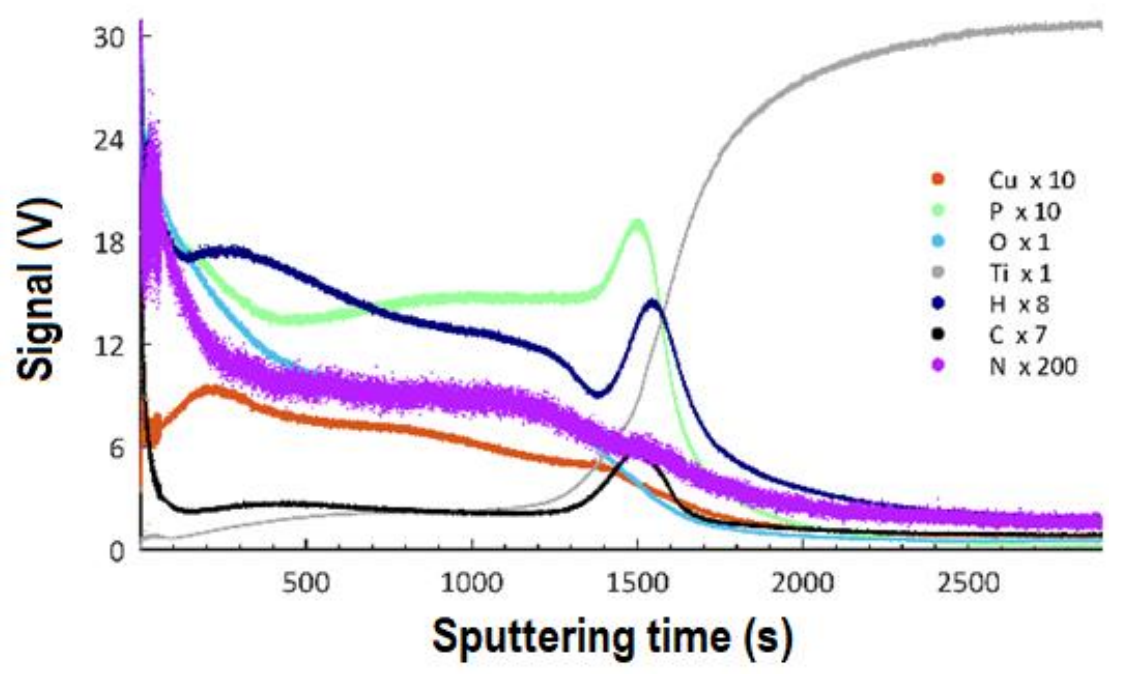

Figure 12. GDOES depth profile of coating obtained in the electrolyte containing $350 \mathrm{~g} / \mathrm{dm}^{3}$ $\mathrm{Cu}(\mathrm{NO})_{3} \cdot 3 \mathrm{H}_{2} \mathrm{O}$ with $\mathrm{PEO}$ voltage of $550 \mathrm{~V}$. The elements $\mathrm{Cu}, \mathrm{P}, \mathrm{O}, \mathrm{Ti}, \mathrm{H}, \mathrm{C}$, and $\mathrm{N}$ may be present in the coatings or result from adsorbed contamination from the atmosphere or cleaning procedure.

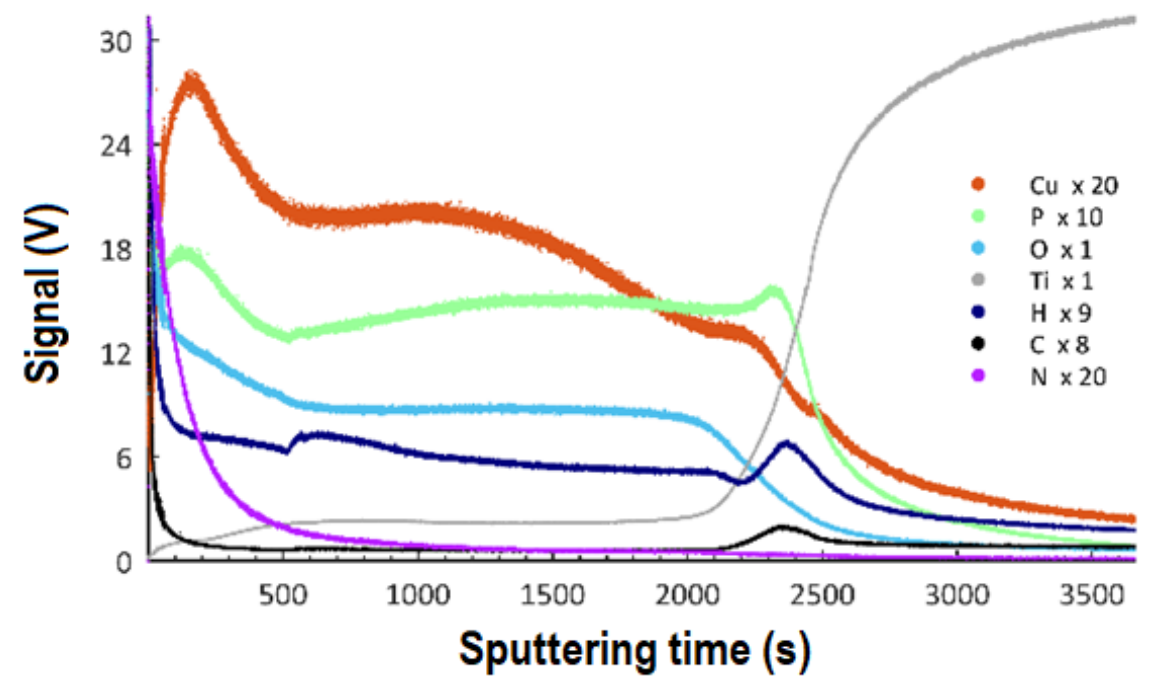

Figure 13. GDOES depth profile of coating obtained in the electrolyte containing $350 \mathrm{~g} / \mathrm{dm}^{3}$ $\mathrm{Cu}(\mathrm{NO})_{3} \cdot 3 \mathrm{H}_{2} \mathrm{O}$ with $\mathrm{PEO}$ voltage of $650 \mathrm{~V}$. The elements $\mathrm{Cu}, \mathrm{P}, \mathrm{O}, \mathrm{Ti}, \mathrm{H}, \mathrm{C}$, and $\mathrm{N}$ may be present in the coatings or result from adsorbed contamination from the atmosphere or cleaning procedure.

The determined depths of the semi-porous layer are approximately $4.0 \mu \mathrm{m}$ for $450 \mathrm{~V}, 7.8 \mu \mathrm{m}$ for $550 \mathrm{~V}$, and $13.9 \mu \mathrm{m}$ for $650 \mathrm{~V}$. The most inner layer of the PEO coatings is a transient layer, connecting the semi-porous layer with the titanium substrate. This transient layer has local maxima for phosphorus, hydrogen, and carbon, after which a fall of the intensity of the corresponding signals is observed. For each of the samples fabricated in the electrolyte containing copper(II) nitrate(V) trihydrate at $350 \mathrm{~g} / \mathrm{dm}^{3}$, the fall of signals of copper, oxygen, and nitrogen is detected, coinciding with the rise of the titanium signal. The determined thicknesses of the transient layers for the samples that were obtained at the voltages of $450 \mathrm{~V}, 550 \mathrm{~V}$, and $650 \mathrm{~V}$, were about $3.7 \mu \mathrm{m}, 8.7 \mu \mathrm{m}$, and $9.6 \mu \mathrm{m}$, respectively. Summing up, the thicknesses of the different sub-layers identified the total thickness of the obtained 
porous $\mathrm{PEO}$ coatings, containing copper, in the electrolyte consisting of $350 \mathrm{~g} \mathrm{Cu}\left(\mathrm{NO}_{3}\right) \cdot 3 \mathrm{H}_{2} \mathrm{O}$ were, as follows: $9.6 \mu \mathrm{m}$ (for $450 \mathrm{~V}$ ), $20.0 \mu \mathrm{m}$ (for $550 \mathrm{~V}$ ), and $27.8 \mu \mathrm{m}$ (for $650 \mathrm{~V}$ ).

\section{Discussion}

Based on the obtained results on surface roughness, it was clear that the parameter $S z$ might be used as the best representative to describe the porous coatings that were obtained on titanium after plasma electrolytic oxidation. An increase of the PEO voltage results in an increase of the $S z$ value, as observed on the 3D maps that were analyzed while using the CLSM technique. An additive model was assumed in order to best describe the effect of the content of copper(II) nitrate(V) trihydrate in the electrolyte on $S z$ at varying voltages of $450 \mathrm{~V}, 550 \mathrm{~V}$, and $650 \mathrm{~V}$, which is summarized in Equation (1) and graphically presented in Figure 14.

$$
\mathrm{Y}=2.3 \times 10^{-7} \times \mathrm{x}_{1}^{3}-2.83 \times 10^{-4} \times \mathrm{x}_{1}^{2}+0,106 \times \mathrm{x}_{1}+0.10 \times \mathrm{x}_{2}-38.7
$$

where $x_{1}$ is the content of the copper(II) nitrate(V) trihydrate in $1 \mathrm{dm}^{3}$ of orthophosphoric acid, and it is expressed in $\mathrm{g} / \mathrm{dm}^{3}$, and $x_{2}$ denotes the voltage of the PEO process expressed in volts-moreover $\mathrm{x}_{1}$ $\in\langle 0-650\rangle$ and $x_{2} \in\langle 450-650\rangle$.

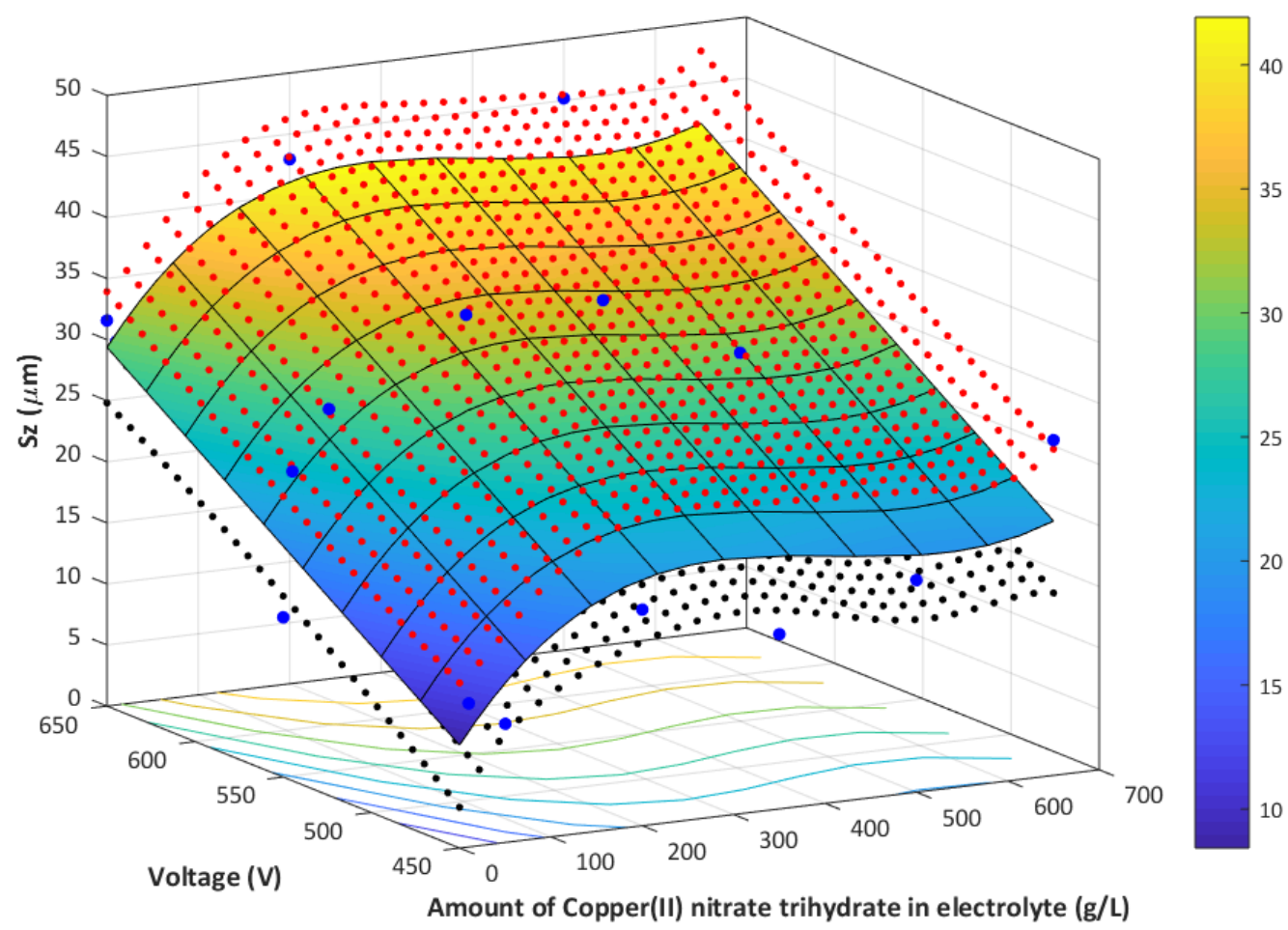

Figure 14. Graphical representation of the mathematical model (blue-yellow gradient), together with the confidence intervals of the model (red points - upper range, blue points - lower range). Sz as a function of the contents of $\mathrm{Cu}\left(\mathrm{NO}_{3}\right)_{2} \cdot 3 \mathrm{H}_{2} \mathrm{O}$ in $1 \mathrm{dm}^{3} \mathrm{H}_{3} \mathrm{PO}_{4}$ and at varying voltages; the confidence interval is the statistical space $(\alpha=0.05)$.

We also propose a model for the variations of the chemical composition of the top $10 \mathrm{~nm}$ surface (measured from XPS data) as a function of the atomic ratio $\mathrm{Cu} / \mathrm{P}$ and the amount of the copper(II) nitrate $(\mathrm{V})$ trihydrate in $1 \mathrm{dm}^{3}$ of orthophosphoric acid for different voltages. This model is a multinomial one, as described by the Equation (2):

$$
\mathrm{Y}=2.15 \times 10^{-10} \times \mathrm{x}_{1}{ }^{3}-5.07 \times 10^{-8} \times \mathrm{x}_{1}^{2}+1.16 \times 10^{-7} \times \mathrm{x}_{1}+0.10 \times \mathrm{x}_{1} \times \mathrm{x}_{2}
$$


where $x_{1}$ is the content of the copper(II) nitrate(V) trihydrate in $1 \mathrm{dm}^{3}$ of orthophosphoric acid, and it is expressed in $\mathrm{g} / \mathrm{dm}^{3}$, and $x_{2}$ denotes the voltage of the PEO process expressed in volts-moreover $\mathrm{x}_{1}$ $\in\langle 0-650\rangle$ and $x_{2} \in\langle 450-650\rangle$. Figure 15 illustrates this model. The multinomial correlation $\left(R^{2}\right)$ equals 0.901 , indicating a relatively good fit.

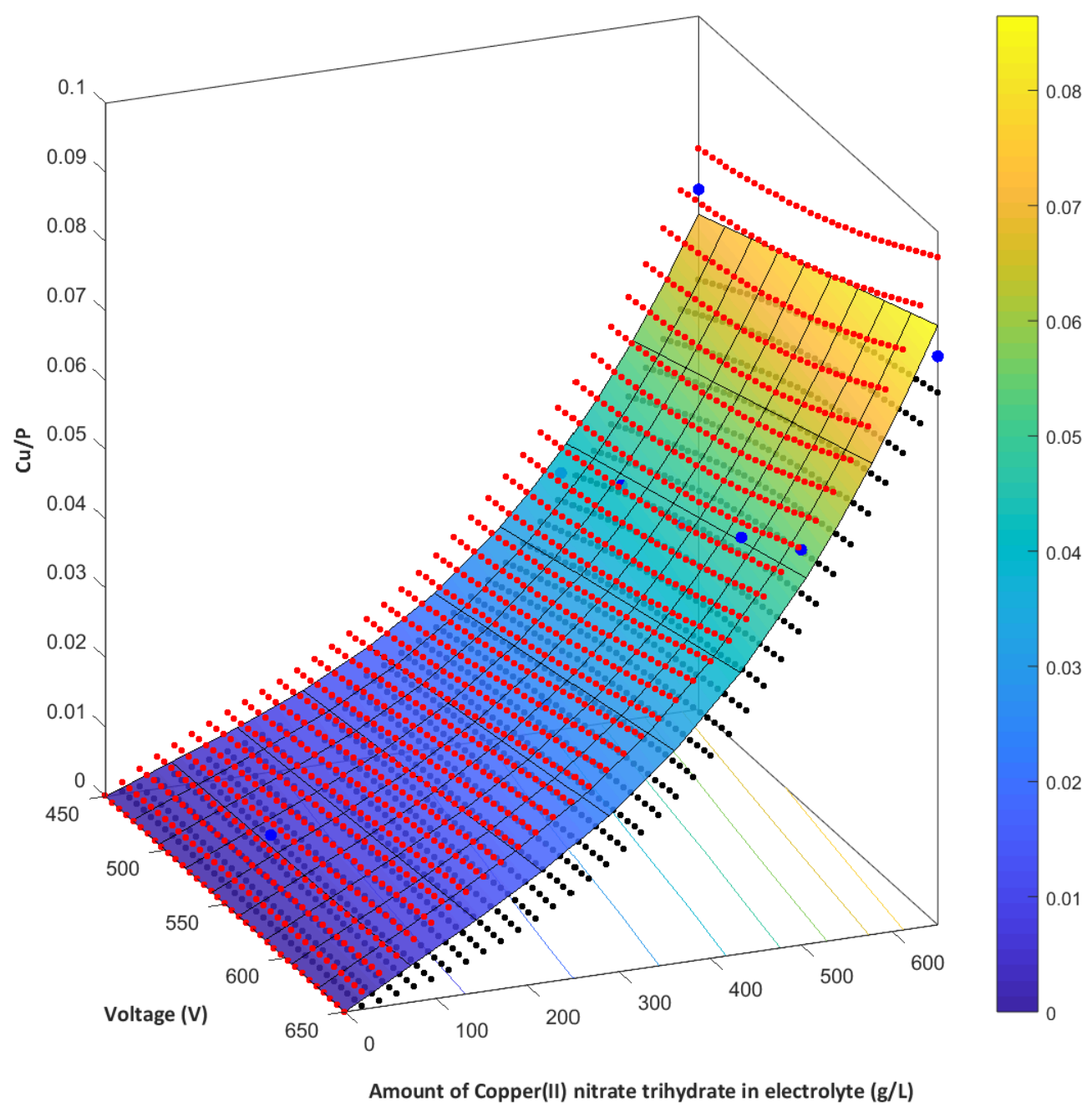

Figure 15. Graphical representation of the mathematical model (blue-yellow gradient), together with the confidence intervals of the model (red points-upper range, blue points-lower range) designated on the basis of the XPS analyses and describing the atomic ratio $\mathrm{Cu} / \mathrm{P}$ (blue points) as a function of the content of $\mathrm{Cu}\left(\mathrm{NO}_{3}\right)_{2} \cdot 3 \mathrm{H}_{2} \mathrm{O}$ in $1 \mathrm{dm}^{3} \mathrm{H}_{3} \mathrm{PO}_{4}$ and the $\mathrm{PEO}$ voltage; the confidence interval is the statistical space $(\alpha=0.05)$.

The EDS results, which characterize the chemical composition of the fabricated PEO coatings, served to establish a mathematical model, characterizing the dependence between the atomic ratio $\mathrm{Cu} / \mathrm{P}$ and the amount of copper(II) nitrate(V) trihydrate in $1 \mathrm{dm}^{3}$ of orthophosphoric acid and the voltage of the PEO process. Equation (3) describes the model $\left(R^{2}=0.843\right)$ and it is displayed in Figure 16.

$$
\mathrm{Y}=5.24 \times 10^{-7} \times \mathrm{x}_{1} \times \mathrm{x}_{2}
$$

where $x_{1}$ is the contents of the copper(II) nitrate(V) trihydrate in $1 \mathrm{dm}^{3}$ of orthophosphoric acid and it is expressed in $\mathrm{g} / \mathrm{dm}^{3}, x_{2}$ is the voltage of the PEO process, expressed in volts, with $\mathrm{x}_{1} \in\langle 200-650\rangle$ and $\mathrm{x}_{2} \in\langle 450-650\rangle$. 


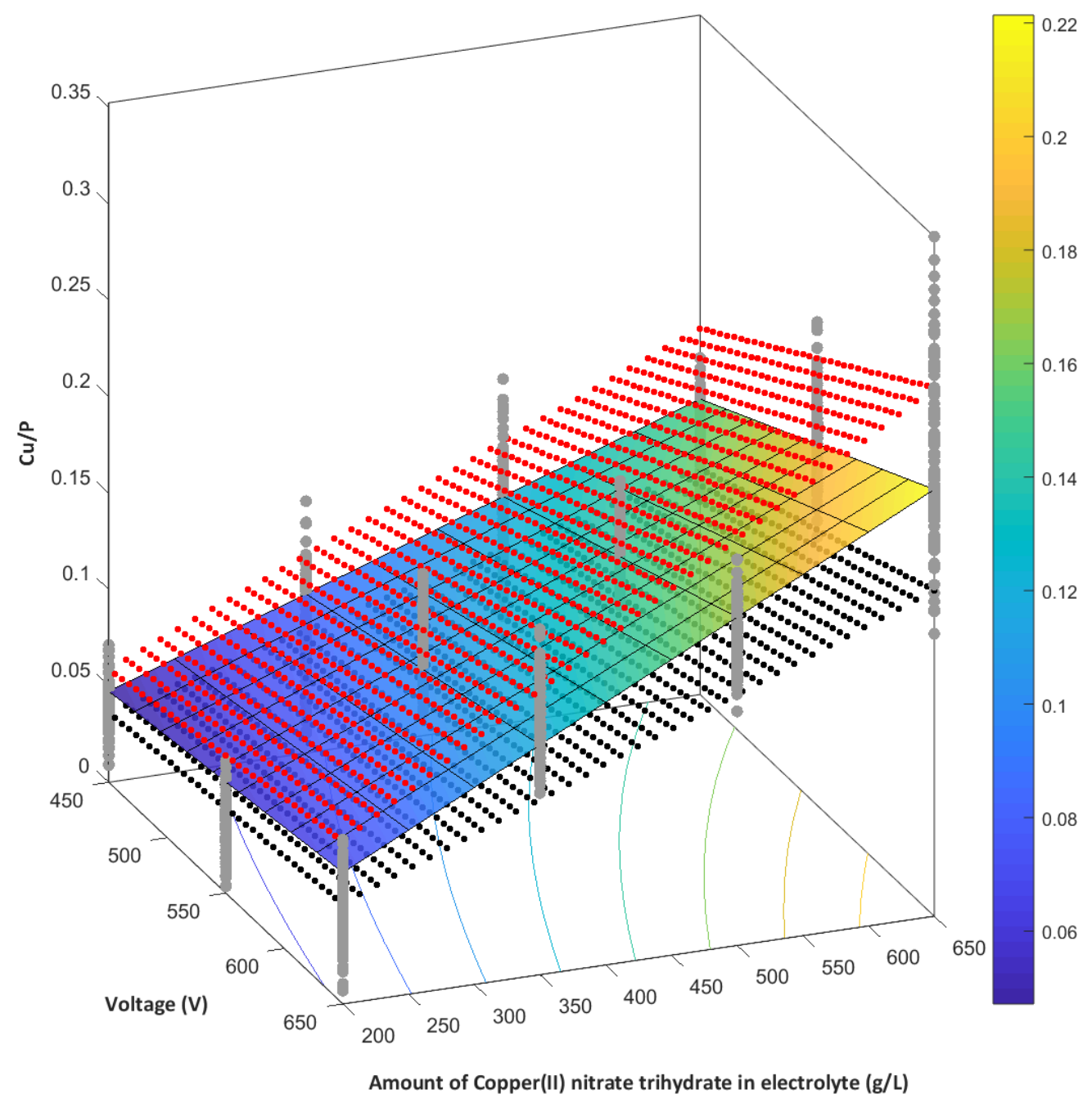

Figure 16. Graphical representation of the mathematical model (blue-yellow gradient), with confidence intervals (red points-upper range, black points-lower range) established from EDS in the second stage of the studies describing the atomic ratio $\mathrm{Cu} / \mathrm{P}$ (blue points) as a function of the content of $\mathrm{Cu}\left(\mathrm{NO}_{3}\right)_{2} \cdot 3 \mathrm{H}_{2} \mathrm{O}$ in $1 \mathrm{dm}^{3} \mathrm{H}_{3} \mathrm{PO}_{4}$ and the $\mathrm{PEO}$ voltage; the confidence interval is the statistical space $(\alpha=0.05)$.

From the GDOES studies (Figure 17), a three-layer model has been proposed, which describes the influence of the PEO voltage on the thicknesses of the different layers of the obtained porous coatings.

A voltage increase in the PEO process from $450 \mathrm{~V}$ up to $650 \mathrm{~V}$ in the same electrolyte $(350 \mathrm{~g}$ $\left.\mathrm{Cu}\left(\mathrm{NO}_{3}\right)_{2} \cdot 3 \mathrm{H}_{2} \mathrm{O}\right)$ results in the growth of the total thickness of the obtained coatings from $9.6 \mu \mathrm{m}$ up to $27.8 \mu \mathrm{m}$. Moreover, one should note that the thickness of each of the designated layers (porous, semi-porous, and a transient one) also increases together with the growth of voltage of the PEO process, with the highest increase being observed in the case of the semi-porous layer. 


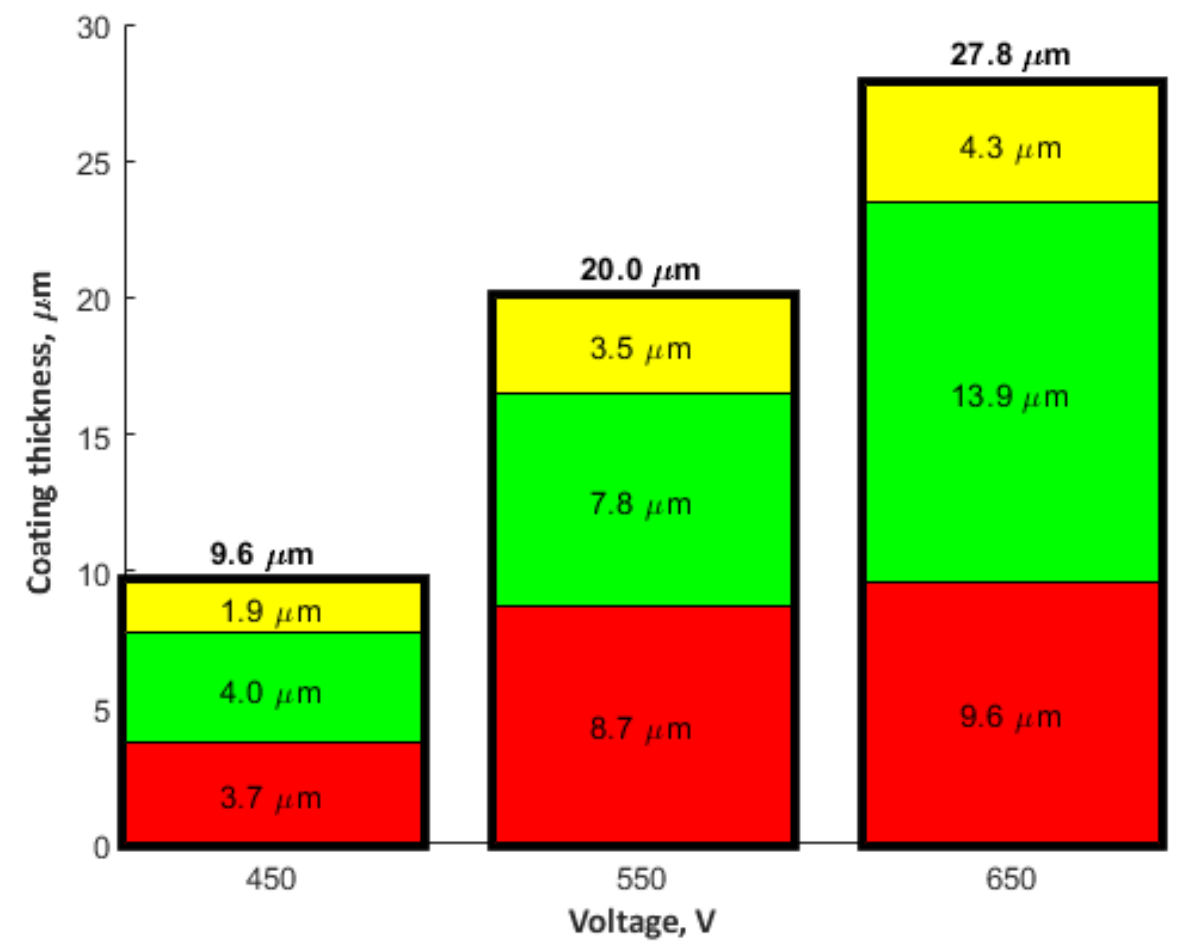

Figure 17. Thickness of the porous layers in the PEO coatings designated on the basis of the GDOES analysis; yellow color-porous layer, green color-semi-porous layer, and red color-transient layer.

\section{Conclusions}

Based on the results that are presented in the present paper it can be concluded that it is possible to fabricate porous coatings enriched in copper, with voltages from $450 \mathrm{~V}$ to $650 \mathrm{~V}$ in the PEO process under DC conditions, in electrolytes based on concentrated orthophosphoric acid with the addition of copper(II) nitrate $(\mathrm{V})$ trihydrate. The following main conclusions may be formulated:

(a) In the obtained PEO coatings, one may distinguish three layers: porous (i), semi-porous (ii), and a transient one (iii); The porous layers are approximately two times thinner than the semi-porous and the transient ones due the fact that the damaging discharges mostly affect the porous layer.

(b) The higher the voltage, the higher the amount of copper in PEO coating.

(c) The higher the amount of $\mathrm{Cu}\left(\mathrm{NO}_{3}\right)_{2} \cdot 3 \mathrm{H}_{2} \mathrm{O}$ used, the higher the amount of copper in PEO coating.

(d) The top $(10 \mathrm{~nm})$ of $\mathrm{PEO}$ coatings contain $\mathrm{Ti}^{4+}, \mathrm{Cu}^{+}$, and $\mathrm{Cu}^{2+}$, as well as $\mathrm{PO}_{4}{ }^{3-}$, and/or $\mathrm{HPO}_{4}{ }^{2-}$, and/or $\mathrm{H}_{2} \mathrm{PO}_{4}^{-}$, and/or $\mathrm{P}_{2} \mathrm{O}_{7}{ }^{2-}$.

(e) The maximum atomic concentration of copper (based on XPS results) in the top surface of PEO coatings equaled $2.59 \%$ for the process that was performed in electrolyte consisting of orthophosphoric acid and the copper(II) nitrate(V) trihydrate of concentration $650 \mathrm{~g} / \mathrm{dm}^{3}$ and voltage of $650 \mathrm{~V}$.

(f) The $\mathrm{Cu} / \mathrm{P}$ ratios (based on XPS results) on the obtained samples, fabricated in electrolyte with $0-650 \mathrm{~g} / \mathrm{dm}^{3} \mathrm{Cu}\left(\mathrm{NO}_{3}\right)_{2}$ and voltages between $450 \mathrm{~V}$ and $650 \mathrm{~V}$, are in the range of 0.009 up to 0.082 .

(g) The $3 \mathrm{D}$ roughness parameters $(\mathrm{Sz} / \mathrm{Sa})$ of the obtained samples, fabricated in electrolyte with $0-650 \mathrm{~g} / \mathrm{dm}^{3} \mathrm{Cu}\left(\mathrm{NO}_{3}\right)_{2}$ and voltages between $450 \mathrm{~V}$ and $650 \mathrm{~V}$, are in the range of $9.72 \mu \mathrm{m} / 0.99 \mu \mathrm{m}$, up to $45.18 \mu \mathrm{m} / 3.42 \mu \mathrm{m}$.

(h) The thicknesses of PEO coatings, obtained in electrolyte with $350 \mathrm{~g} / \mathrm{dm}^{3} \mathrm{Cu}\left(\mathrm{NO}_{3}\right)_{2}$ and at voltages between $450 \mathrm{~V}$ and $650 \mathrm{~V}$, are in the range from $9.6 \mu \mathrm{m}$ up to $27.8 \mu \mathrm{m}$. 
Supplementary Materials: The following are available online at http://www.mdpi.com/1996-1944/13/6/1295/s1, Figure S1: Juxtaposition of exemplary SEM images (a-l) and 3D maps obtained by using CLSM technique (m-o) on the PEO coatings fabricated with an electrolyte of concentrated orthophosphoric acid at voltages: $450 \mathrm{~V}(\mathrm{a}, \mathrm{d}, \mathrm{g}$, j, m), $550 \mathrm{~V}(\mathrm{~b}, \mathrm{e}, \mathrm{h}, \mathrm{k}, \mathrm{n})$, and $650 \mathrm{~V}$ (c, f, i, l), Figure S2: Examples of SEM images (a-l) and 3D maps obtained by CLSM (m-o) on the PEO coatings fabricated in an electrolyte consisting of orthophosphoric acid and copper (II) nitrate $(\mathrm{V})$ trihydrate of concentration $10 \mathrm{~g} / \mathrm{dm}^{3}$ at the voltages: $450 \mathrm{~V}(\mathrm{a}, \mathrm{d}, \mathrm{g}, \mathrm{j}, \mathrm{m}), 550 \mathrm{~V}(\mathrm{~b}, \mathrm{e}, \mathrm{h}, \mathrm{k}, \mathrm{n})$, and $650 \mathrm{~V}$ $(c, f, i, l)$, Figure S3: Examples of SEM SEM images (a-l) and 3D maps obtained by using CLSM technique $(m-o)$ on the PEO coatings fabricated in the electrolyte consisting of the orthophosphoric acid and the copper (II) nitrate (V) trihydrate of concentration $50 \mathrm{~g} / \mathrm{dm}^{3}$ at the voltages: $450 \mathrm{~V}(\mathrm{a}, \mathrm{d}, \mathrm{g}, \mathrm{j}, \mathrm{m}), 550 \mathrm{~V}(\mathrm{~b}, \mathrm{e}, \mathrm{h}, \mathrm{k}, \mathrm{n})$, and $650 \mathrm{~V}(\mathrm{c}, \mathrm{f}, \mathrm{i}, \mathrm{l})$, Figure S4: Examples of SEM images (a-l) and 3D maps obtained by CLSM (m-o) on the PEO coatings fabricated in an electrolyte consisting of orthophosphoric acid and copper (II) nitrate (V) trihydrate of concentration 200 $\mathrm{g} / \mathrm{dm}^{3}$ at the voltages: $450 \mathrm{~V}(\mathrm{a}, \mathrm{d}, \mathrm{g}, \mathrm{j}, \mathrm{m}), 550 \mathrm{~V}(\mathrm{~b}, \mathrm{e}, \mathrm{h}, \mathrm{k}, \mathrm{n})$, and $650 \mathrm{~V}(\mathrm{c}, \mathrm{f}, \mathrm{i}, \mathrm{l})$, Figure S5: Examples of SEM images (a-1) and 3D maps obtained by CLSM (m-o) on the PEO coatings fabricated in an electrolyte consisting of orthophosphoric acid and copper (II) nitrate (V) trihydrate of concentration $350 \mathrm{~g} / \mathrm{dm}^{3}$ at voltages: $450 \mathrm{~V}(\mathrm{a}, \mathrm{d}, \mathrm{g}, \mathrm{j}$, $\mathrm{m}), 550 \mathrm{~V}(\mathrm{~b}, \mathrm{e}, \mathrm{h}, \mathrm{k}, \mathrm{n})$, and $650 \mathrm{~V}(\mathrm{c}, \mathrm{f}, \mathrm{i}, \mathrm{l})$, Figure S6: Examples of SEM images (a-l) and 3D maps obtained by CLSM $(\mathrm{m}-\mathrm{O})$ on the PEO coatings fabricated in an electrolyte consisting of orthophosphoric acid and copper (II) nitrate (V) trihydrate of concentration $500 \mathrm{~g} / \mathrm{dm}^{3}$ at the voltages: $450 \mathrm{~V}(\mathrm{a}, \mathrm{d}, \mathrm{g}, \mathrm{j}, \mathrm{m}), 550 \mathrm{~V}(\mathrm{~b}, \mathrm{e}, \mathrm{h}, \mathrm{k}, \mathrm{n})$, and $650 \mathrm{~V}(\mathrm{c}, \mathrm{f}, \mathrm{i}, \mathrm{l})$, Figure S7: Examples of SEM images (a-l) and 3D maps obtained by CLSM (m-o) on the PEO coatings fabricated in an electrolyte consisting of orthophosphoric acid and copper (II) nitrate (V) trihydrate of concentration $650 \mathrm{~g} / \mathrm{dm}^{3}$ at the voltages: $450 \mathrm{~V}(\mathrm{a}, \mathrm{d}, \mathrm{g}, \mathrm{j}, \mathrm{m}), 550 \mathrm{~V}(\mathrm{~b}, \mathrm{e}, \mathrm{h}, \mathrm{k}, \mathrm{n})$, and $650 \mathrm{~V}(\mathrm{c}, \mathrm{f}, \mathrm{i}, \mathrm{l})$., Figure S8: XPS spectra obtained for the PEO coating fabricated in the electrolyte consisting of orthophosphoric acid and copper(II) nitrate(V) trihydrate at concentration $50 \mathrm{~g} / \mathrm{dm}^{3}$ with a voltage of $550 \mathrm{~V}$, Figure S9: XPS spectra obtained for the PEO coating fabricated in the electrolyte consisting of orthophosphoric acid and copper(II) nitrate(V) trihydrate at concentration $350 \mathrm{~g} / \mathrm{dm}^{3}$ and voltage of $550 \mathrm{~V}$, Figure S10: XPS spectra obtained for the PEO coating fabricated in the electrolyte consisting of orthophosphoric acid and copper(II) nitrate(V) trihydrate at concentration $500 \mathrm{~g} / \mathrm{dm}^{3}$ and voltage of $450 \mathrm{~V}$, Figure S11: XPS spectra obtained for the PEO coating fabricated in the electrolyte consisting of orthophosphoric acid and copper(II) nitrate(V) trihydrate at concentration $500 \mathrm{~g} / \mathrm{dm}^{3}$ and voltage of $500 \mathrm{~V}$, Figure S12: XPS spectra obtained for the PEO coating fabricated in the electrolyte consisting of orthophosphoric acid and copper(II) nitrate(V) trihydrate at concentration $500 \mathrm{~g} / \mathrm{dm}^{3}$ and voltage of $550 \mathrm{~V}$, Figure S13: XPS spectra obtained for the PEO coating fabricated in the electrolyte consisting of orthophosphoric acid and copper(II) nitrate(V) trihydrate at concentration $500 \mathrm{~g} / \mathrm{dm}^{3}$ and voltage of $600 \mathrm{~V}$, Figure S14: XPS spectra obtained for the PEO coating fabricated in the electrolyte consisting of orthophosphoric acid and copper(II) nitrate(V) trihydrate at concentration $500 \mathrm{~g} / \mathrm{dm}^{3}$ and voltage of $650 \mathrm{~V}$, Figure S15: XPS spectra obtained for the PEO coating fabricated in the electrolyte consisting orthophosphoric acid and the copper(II) nitrate(V) trihydrate of concentration $650 \mathrm{~g} / \mathrm{dm}^{3}$ and voltage of $450 \mathrm{~V}$, Figure S16: XPS spectra obtained for the PEO coating fabricated in the electrolyte consisting orthophosphoric acid and the copper(II) nitrate(V) trihydrate of concentration $650 \mathrm{~g} / \mathrm{dm}^{3}$ and voltage of $650 \mathrm{~V}$, Figure S17: XRD diffractogram obtained for the PEO coating fabricated in the electrolyte consisting of orthophosphoric acid and copper(II) nitrate(V) trihydrate at concentration $10 \mathrm{~g} / \mathrm{dm}^{3}$ with a voltage of $550 \mathrm{~V}$, Figure S18: XRD diffractogram obtained for the PEO coating fabricated in the electrolyte consisting of orthophosphoric acid and copper(II) nitrate $(\mathrm{V})$ trihydrate at concentration $50 \mathrm{~g} / \mathrm{dm}^{3}$ and voltage of $550 \mathrm{~V}$, Figure S19: XRD diffractogram obtained for the PEO coating fabricated in the electrolyte consisting of orthophosphoric acid and copper(II) nitrate(V) trihydrate at concentration $200 \mathrm{~g} / \mathrm{dm}^{3}$ and voltage of $550 \mathrm{~V}$, Figure S20: XRD diffractogram obtained for the PEO coating fabricated in the electrolyte consisting of orthophosphoric acid and copper(II) nitrate(V) trihydrate at concentration $350 \mathrm{~g} / \mathrm{dm}^{3}$ and voltage of $550 \mathrm{~V}$, Figure S21: XRD diffractogram obtained for the PEO coating fabricated in the electrolyte consisting of orthophosphoric acid and copper(II) nitrate(V) trihydrate at concentration $500 \mathrm{~g} / \mathrm{dm}^{3}$ and voltage of $550 \mathrm{~V}$, Figure S22: XRD diffractogram obtained for the PEO coating fabricated in the electrolyte consisting of orthophosphoric acid and copper(II) nitrate(V) trihydrate at concentration $500 \mathrm{~g} / \mathrm{dm}^{3}$ and voltage of $450 \mathrm{~V}$, Figure S23: XRD diffractogram obtained for the PEO coating fabricated in the electrolyte consisting of orthophosphoric acid and copper(II) nitrate(V) trihydrate at concentration $500 \mathrm{~g} / \mathrm{dm}^{3}$ and voltage of $650 \mathrm{~V}$, Figure S24: XRD diffractogram obtained for the PEO coating fabricated in the electrolyte consisting orthophosphoric acid and the copper(II) nitrate(V) trihydrate of concentration $650 \mathrm{~g} / \mathrm{dm}^{3}$ and voltage of 550 V, Table S1: Results of surface topography parameters using CLSM method, on a titanium sample after PEO processing in a pure concentrated orthophosphoric acid electrolyte at different voltages $450 \mathrm{~V}, 550 \mathrm{~V}$, and $650 \mathrm{~V}$, Table S2: Results of surface topography parameters for a titanium sample after PEO processing in an electrolyte with $10 \mathrm{~g} / \mathrm{dm}^{3}$ of $\mathrm{Cu}\left(\mathrm{NO}_{3}\right)_{2} \cdot 3 \mathrm{H}_{2} \mathrm{O}$ amounting at the voltages of $450 \mathrm{~V}, 550 \mathrm{~V}$, and $650 \mathrm{~V}$, Table S3: Results of surface topography parameters for a titanium sample after PEO processing in an electrolyte with $50 \mathrm{~g} / \mathrm{dm}^{3}$ of $\mathrm{Cu}\left(\mathrm{NO}_{3}\right)_{2} \cdot 3 \mathrm{H}_{2} \mathrm{O}$ amounting at the voltages of $450 \mathrm{~V}, 550 \mathrm{~V}$, and $650 \mathrm{~V}$, Table S4: Results of surface topography parameters for a titanium sample after PEO processing in an electrolyte with $200 \mathrm{~g} / \mathrm{dm}^{3}$ of $\mathrm{Cu}\left(\mathrm{NO}_{3}\right)_{2} \cdot 3 \mathrm{H}_{2} \mathrm{O}$ amounting at the voltages of $450 \mathrm{~V}, 550 \mathrm{~V}$, and $650 \mathrm{~V}$, Table S5: Results of surface topography parameters for a titanium sample after PEO processing in an electrolyte with $350 \mathrm{~g} / \mathrm{dm}^{3}$ of $\mathrm{Cu}\left(\mathrm{NO}_{3}\right)_{2} \cdot 3 \mathrm{H}_{2} \mathrm{O}$ amounting at the voltages of $450 \mathrm{~V}, 550 \mathrm{~V}$, and $650 \mathrm{~V}$, Table S6: Results of surface topography parameters for a titanium sample after PEO processing in an electrolyte with $500 \mathrm{~g} / \mathrm{dm}^{3}$ of $\mathrm{Cu}\left(\mathrm{NO}_{3}\right)_{2} \cdot 3 \mathrm{H}_{2} \mathrm{O}$ amounting at the voltages of $450 \mathrm{~V}, 550 \mathrm{~V}$, 
and $650 \mathrm{~V}$, Table S7: Results of surface topography parameters for a titanium sample after PEO processing in an electrolyte with $650 \mathrm{~g} / \mathrm{dm}^{3}$ of $\mathrm{Cu}\left(\mathrm{NO}_{3}\right)_{2} \cdot 3 \mathrm{H}_{2} \mathrm{O}$ amounting at the voltages of $450 \mathrm{~V}, 550 \mathrm{~V}$, and $650 \mathrm{~V}$.

Author Contributions: K.R. and Ł.D. conceived and designed the experiments; K.R., S.G., P.C., S.R., D.M., K.T., and W.M. performed the experiments; K.R., T.H., W.K., Ł.D., and K.P. analyzed the data; K.R., Ł.D. and K.P. contributed reagents, materials, analysis tools; K.R., T.H. and Ł.D. wrote the paper. All authors have read and agreed to the published version of the manuscript.

Funding: This work was supported by a subsidy from Grant OPUS 11 of National Science Centre, Poland, with registration number 2016/21/B/ST8/01952, titled "Development of models of new porous coatings obtained on titanium by Plasma Electrolytic Oxidation in electrolytes containing phosphoric acid with addition of calcium, magnesium, copper and zinc nitrates".

Conflicts of Interest: The authors declare no conflict of interest.

\section{References}

1. Rokosz, K.; Hryniewicz, T.; Raaen, S.; Chapon, P.; Dudek, L. GDOES, XPS, and SEM with EDS analysis of porous coatings obtained on titanium after plasma electrolytic oxidation. Surf. Interface Anal. 2017, 49, 303-315. [CrossRef]

2. Rokosz, K.; Hryniewicz, T.; Raaen, S.; Chapon, P. Investigation of porous coatings obtained on Ti-Nb-Zr-Sn alloy biomaterial by plasma electrolytic oxidation: Characterisation and modelling. Int. J. Adv. Manuf. Technol. 2016, 87, 3497-3512. [CrossRef]

3. Rokosz, K.; Hryniewicz, T.; Matysek, D.; Dudek, L.; Malorny, W. SEM and EDS analysis of nitinol surfaces treated by plasma electrolytic oxidation. Adv. Mater. Sci. 2015, 15, 41-47. [CrossRef]

4. Rokosz, K.; Hryniewicz, T.; Raaen, S.; Matysek, D.; Dudek, L.; Pietrzak, K. SEM, EDS, and XPS characterization of coatings obtained on titanium during AC plasma electrolytic process enriched in magnesium. Adv. Mater. Sci. 2018, 18, 68-78. [CrossRef]

5. Marques, I.S.V.; Nilson, C.C.; Landers, R.; Yuan, J.C.C.; Mesquita, M.F.; Sukotjo, C.; Mathew, T.; Barao, V.A.D. Incorporation of $\mathrm{Ca}, \mathrm{P}$, and $\mathrm{Si}$ on bioactive coatings produced by plasma electrolytic oxidation: The role of electrolyte concentration and treatment duration. Biointerphases 2015, 10, 1-12. [CrossRef] [PubMed]

6. Zhang, L.; Guo, J.Q.; Huang, X.Y.; Zhang, Y.N.; Han, Y. The dual function of Cu-doped $\mathrm{TiO}_{2}$ coatings on titanium for application in percutaneous implants. J. Mater. Chem. B 2016, 4, 3788-3800. [CrossRef]

7. Zhou, R.; Wei, D.; Cheng, S.; Zhou, Y.; Jia, D.; Wang, Y.; Li, B. The effect of titanium bead diameter of porous titanium on the formation of micro-arc oxidized $\mathrm{TiO}_{2}$-based coatings containing $\mathrm{Si}$ and Ca. Ceram. Int. 2013, 39, 5725-5732. [CrossRef]

8. Yavari, S.A.; Necula, B.S.; Fratila-Apachitei, L.E.; Duszczyk, J.; Apachitei, I. Biofunctional surfaces by plasma electrolytic oxidation on titanium biomedical alloys. Surf. Eng. 2016, 32, 411-417. [CrossRef]

9. Zhou, R.; Wei, D.; Yang, H.; Cheng, S.; Feng, W.; Li, B.; Wang, Y.; Jia, D.; Zhou, Y. Osseointegration of bioactive microarc oxidized amorphous phase $/ \mathrm{TiO}_{2}$ nanocrystals composited coatings on titanium after implantation into rabbit tibia. J. Mater. Sci. Mater. Med. 2014, 25, 1307-1318. [CrossRef]

10. Mirelman, L.K.; Curran, J.A.; Clyne, T.W. The production of anatase-rich photoactive coatings by plasma electrolytic oxidation. Surf. Coat. Technol. 2012, 207, 66-71. [CrossRef]

11. Peláez-Abellán, E.; Duarte, L.T.; Biaggio, S.R.; Rocha-Filho, R.C.; Bocchi, N. Modification of the titanium oxide morphology and composition by a combined chemical-electrochemical treatment on cp Ti. Mater. Res. 2012, 15, 159-165. [CrossRef]

12. Zhu, L.; Ye, X.; Tang, G.; Zhao, N.; Gong, Y.; Zhao, Y.; Zhao, J.; Zhang, X. Corrosion test, cell behavior test, and in vivo study of gradient $\mathrm{TiO}_{2}$ layers produced by compound electrochemical oxidation. J. Biomed. Mater. Res. A 2006, 78, 515-522. [CrossRef] [PubMed]

13. Terleeva, O.P.; Sharkeev, Y.P.; Slonova, A.I.; Mironov, I.V.; Legostaeva, E.V.; Khlusov, I.A.; Matykina, E.; Skeldon, P.; Thompson, G.E. Effect of microplasma modes and electrolyte composition on micro-arc oxidation coatings on titanium for medical applications. Surf. Coat. Technol. 2010, 205, 1723-1729. [CrossRef]

14. Wang, S.; Zhao, Q.; Liu, D.; Du, N. Microstructure and elevated temperature tribological behavior of $\mathrm{TiO}_{2} / \mathrm{Al}_{2} \mathrm{O}_{3}$ composite ceramic coating formed by microarc oxidation of Ti6Al4V alloy. Surf. Coat. Technol. 2015, 272, 343-349. [CrossRef]

15. Teh, T.H.; Berkani, A.; Mato, S.; Skeldon, P.; Thompson, G.E.; Habazaki, H.; Shimizu, K. Initial stages of plasma electrolytic oxidation of titanium. Corros. Sci. 2003, 45, 2757-2768. [CrossRef] 
16. Hariprasad, S.; Ashfaq, M.; Arunnellaiappan, T.; Harilal, M.; Rameshbabu, N. Role of electrolyte additives on in-vitro corrosion behavior of DC plasma electrolytic oxidization coatings formed on CP-Ti. Surf. Coat. Technol. 2016, 292, 20-29.

17. Rudnev, V.S.; Yarovaya, T.P.; Egorkin, V.S.; Sinebryukov, S.L.; Gnedenkov, S.V. Properties of coatings formed on titanium by plasma electrolytic oxidation in a phosphate-borate electrolyte. Russ. J. Appl. Chem. 2010, 83, 664-670. [CrossRef]

18. Sharifi, H.; Aliofkhazraei, M.; Darband, G.; Rouhaghdam, A.S. Characterization of PEO nanocomposite coatings on titanium formed in electrolyte containing atenolol. Surf. Coat. Technol. 2016, 304, 438-449. [CrossRef]

19. Tang, H.; Sun, Q.; Yi, C.G.; Jiang, Z.H.; Wang, F.P. High emissivity coatings on titanium alloy prepared by micro-arc oxidation for high temperature application. J. Mater. Sci. 2012, 47, 2162-2168. [CrossRef]

20. Tang, H.; Xin, T.Z.; Sun, Q.; Yi, C.G.; Jiang, Z.H.; Wang, F.P. Influence of $\mathrm{FeSO}_{4}$ concentration on thermal emissivity of coatings formed on titanium alloy by micro-arc oxidation. Appl. Surf. Sci. 2011, 257, 10839-10844. [CrossRef]

21. Tang, H.; Sun, Q.; Xin, T.Z.; Yi, C.G.; Jiang, Z.H.; Wang, F.P. Influence of $\mathrm{Co}\left(\mathrm{CH}_{3} \mathrm{COO}\right)_{2}$ concentration on thermal emissivity of coatings formed on titanium alloy by micro-arc oxidation. Curr. Appl. Phys. 2012, 12, 284-290. [CrossRef]

22. Aliasghari, S. Plasma Electrolytic Oxidation of Titanium. Ph.D. Thesis, The University of Manchester, Manchester, UK, 2014.

23. Liu, S.M.; Yang, X.J.; Cui, Z.D.; Zhu, S.L.; Wei, Q. One-step synthesis of petal-like apatite/titania composite coating on a titanium by micro-arc treating. Mater. Lett. 2011, 65, 1041-1044. [CrossRef]

24. Zhang, W.; Du, K.; Yan, C.; Wang, F. Preparation and characterization of a novel Si-incorporated ceramic film on pure titanium by plasma electrolytic oxidation. Appl. Surf. Sci. 2008, 254, 5216-5223. [CrossRef]

25. Rokosz, K.; Hryniewicz, T.; Kacalak, W.; Tandecka, K.; Raaen, S.; Gaiaschi, S.; Chapon, P.; Malorny, W.; Matysek, D.; Dudek, L.; et al. Characterization of Porous Phosphate Coatings Enriched with Calcium, Magnesium, Zinc and Copper Created on CP Titanium Grade 2 by Plasma Electrolytic Oxidation. Metals 2018, 8, 112. [CrossRef] 